\title{
WestVirginiaUniversity
}

THE RESEARCH REPOSITORY @ WVU

Graduate Theses, Dissertations, and Problem Reports

2020

\section{Potential Benefits from Practices in Construction Waste Material Controls}

\author{
Abdulaziz Alwadhenani \\ asalwadhenani@mix.wvu.edu
}

Follow this and additional works at: https://researchrepository.wvu.edu/etd

Part of the Civil Engineering Commons, and the Construction Engineering and Management Commons

\section{Recommended Citation}

Alwadhenani, Abdulaziz, "Potential Benefits from Practices in Construction Waste Material Controls" (2020). Graduate Theses, Dissertations, and Problem Reports. 7809.

https://researchrepository.wvu.edu/etd/7809

This Problem/Project Report is protected by copyright and/or related rights. It has been brought to you by the The Research Repository @WVU with permission from the rights-holder(s). You are free to use this Problem/Project Report in any way that is permitted by the copyright and related rights legislation that applies to your use. For other uses you must obtain permission from the rights-holder(s) directly, unless additional rights are indicated by a Creative Commons license in the record and/ or on the work itself. This Problem/Project Report has been accepted for inclusion in WVU Graduate Theses, Dissertations, and Problem Reports collection by an authorized administrator of The Research Repository @ WVU. For more information, please contact researchrepository@mail.wvu.edu. 


\title{
Potential Benefits from Practices in Construction Waste Material Controls
}

\author{
Abdulaziz Alwadhenani \\ Problem Report submitted to the Statler College of Engineering and Mineral Resources \\ at West Virginia University
}

in partial fulfillment of the requirements for the degree of

Master of Science

in

Civil and Environmental Engineering

Yoojung Yoon, Ph.D., Co-Chair

Radhey Sharma, Ph.D., Co-Chair

Fei Dai, Ph.D., Committee Member

Department of Civil and Environmental Engineering

Morgantown, West Virginia

2020

Keywords: Construction, debris, waste, (environmental, economic, safety) impacts, Construction waste management.

Copyright 2020 Abdulaziz Alwadhenani 


\section{Abstract \\ Potential Benefits from Practices in Construction Waste Material Controls}

Abdulaziz Alwadhenani

Construction waste is generated from the various construction activities of building, maintaining, renovating, and demolishing infrastructure facilities. These materials include, but are not limited to, concrete, rubble, fiberglass, asphalt, bricks, wood, and scrap metals. In the last few decades, there has been a significant increase in the volume of construction and demolition (C\&D) waste materials in the United States (U.S.). Between 1990 and 2017, the total increase in debris generation has surpassed 320\%. According to U.S. solid waste management statistics, more than $50 \%$ of $C \& D$ waste has been and continues to be transported to landfills. The disposal of C\&D waste materials in landfills can adversely affect the environment and is not viable economically. Also, C\&D waste materials left on construction sites can threaten the safety of construction workers. The application of strategic C\&D waste management practices through reducing, recycling, and reusing waste materials is essential for sustainable management of limited resources and thereby can benefit the environment, construction safety, and the economy. For example, the advantages of C\&D waste management include reduced environmental pollution, expanded job opportunities, savings in construction project expenses, and enhanced safety for construction workers. The objective of this research was to explore various construction waste management practices to control C\&D waste as well as the potential benefits they may bring to the environment, construction safety, and the economy. The findings of this research can be summarized as follows: 1) most construction companies do not deal with waste seriously that is the reason for high practice in landfilling. 2) the best way to minimize the harmful effect of construction waste is by following construction waste management practices, and 3) recycling construction waste is more costeffective than dispose the waste. 


\section{Acknowledgments}

I would like to express my sincere gratitude to many people who made this research possible. Firstly, I would to like to thank my research advisors Dr. Yoojung Yoon and Dr. Radhey Sharma for their continuous support and their guidance to help me in writing and overcoming this research. I especially thank Dr. Yoon for his patience, motivation and knowledge he provided me through this research. Also, I want to thank Dr. Sharma for supporting me and getting me into the master's program. I could not imagine having better advisors and mentor for my master's study. Furthermore, I would thank Dr. Fei Dai for generously serving as a third committee member in my final defense. I thank the Department of Environmental and Civil Engineering for allowing me to pursue my passion in this research.

I am extremely grateful to my parents for their love, support, prayers, and caring about my education and future. I want to show my gratitude for siblings and friends for their love, acceptance, and patience to help me going through difficulties and completing this research. Lastly, my sincere thanks go to the Saudi embassy for sponsoring my master's and give me a chance to follow my passion. 


\section{Contents}

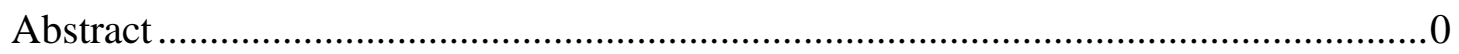

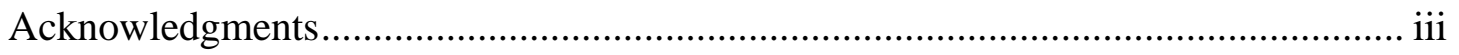

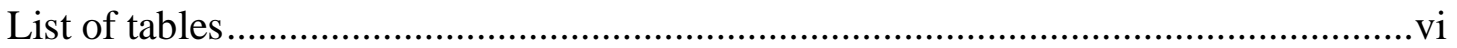

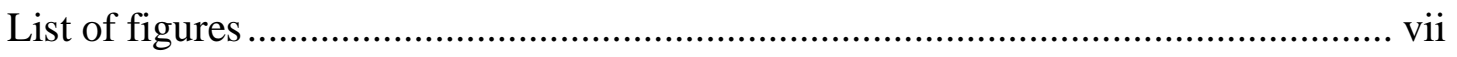

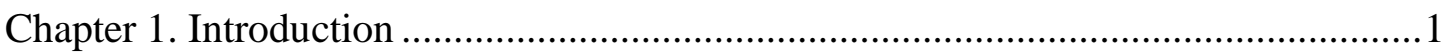

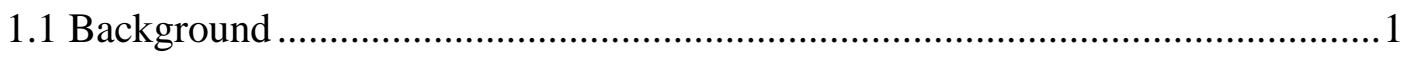

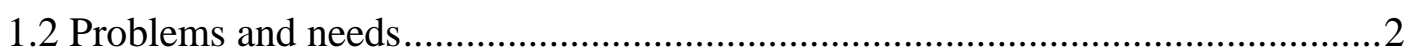

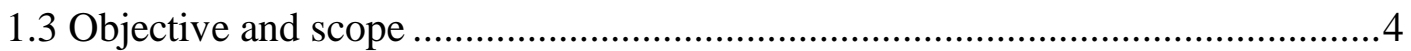

Chapter 2. Construction waste impacts on the environment, safety, and economy.......5

2.1 Landfill and energy saving impacts on the environment .................................5

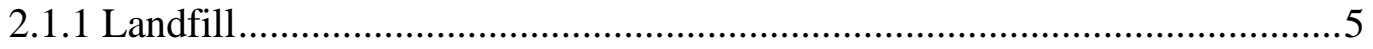

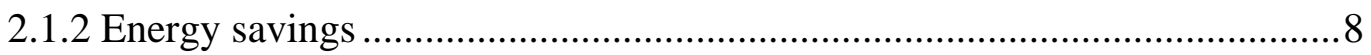

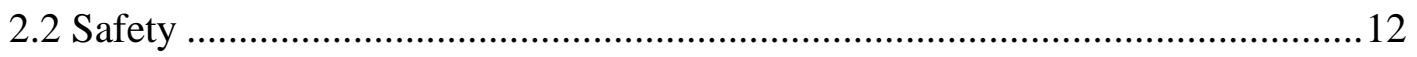

2.2.1 Traffic safety, loading, and unloading .................................................. 12

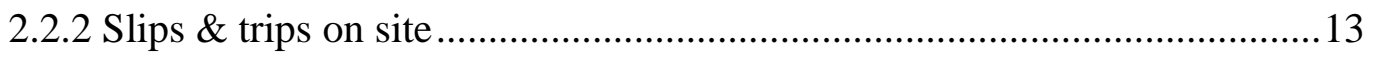

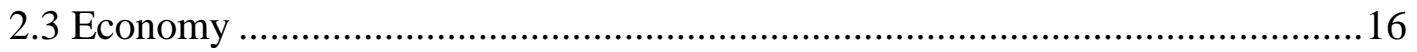

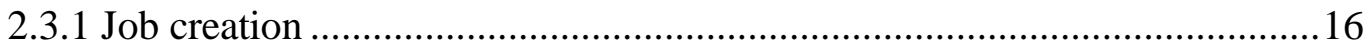

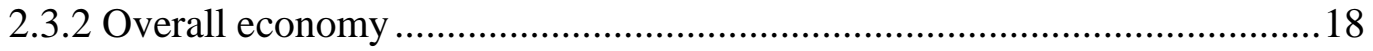

Chapter 3. Construction waste management ..........................................................22

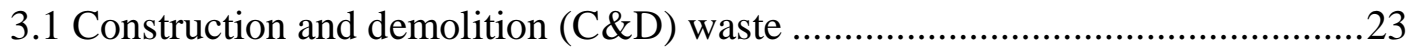

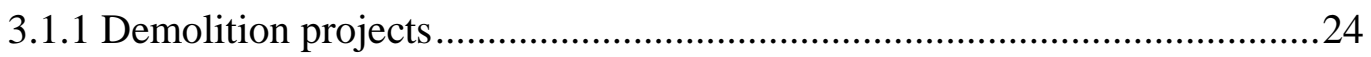

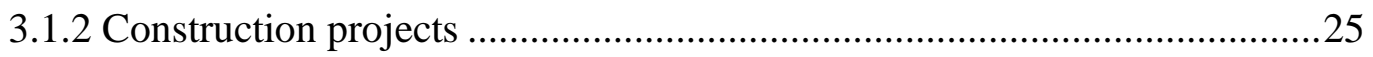

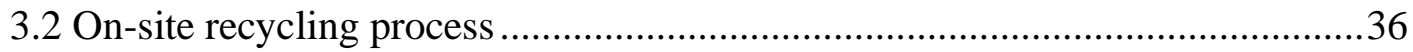

3.2.1 Recycling demolition waste processes .....................................................39

3.2.2 Recycling construction waste processes ................................................41

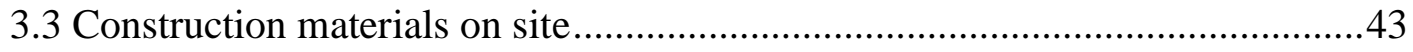

3.3.1 Most useful materials in construction sites ...............................................44

3.3.2 Possible harmful materials or waste on construction sites.........................49

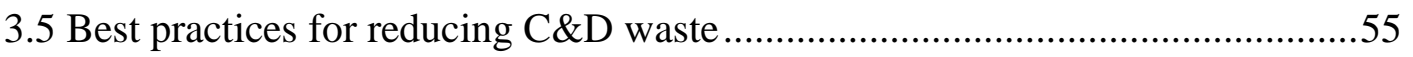


3.5.1 Designing for adaptability, disassembly, and reuse... .55

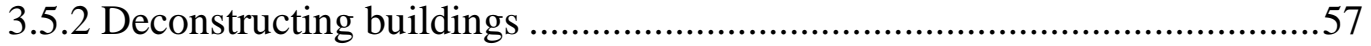

Chapter 4. Recommendations \& conclusion............................................................59

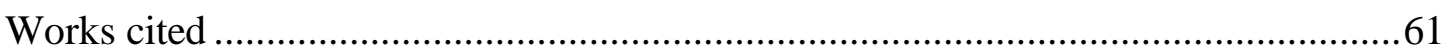




\section{List of tables}

Table 1: Millions of tons recycled of each category and the corresponding ........................... 7

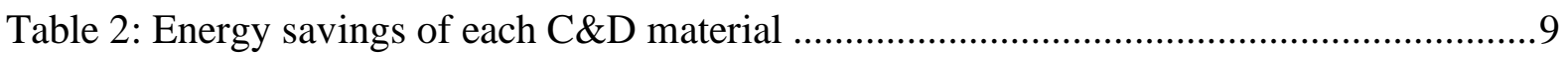

Table 3: Metric tons of CO2 equivalent avoided of each C\&D material ..............................11

Table 4: Millions of tons recycled in each category and the corresponding jobs ...................17

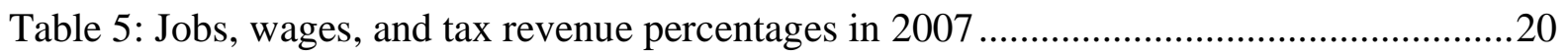

Table 6: C\&D debris generation by source (million tons) Year of 2012 ..............................28

Table 7: C\&D debris generation by source (million tons) Year of 2013..............................29

Table 8:C\&D debris generation by source (million tons) Year of 2014 .................................30

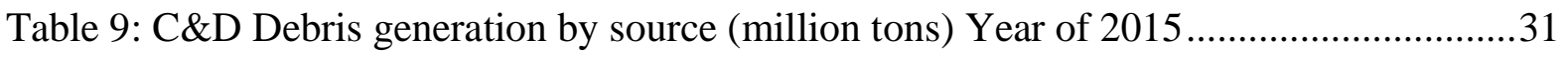

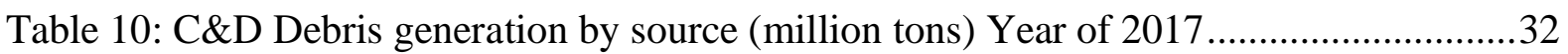

Table 11: Typical components/materials with a high recovery potential ..............................33

Table 12: Salvage values for some recovered materials .......................................................34 


\section{List of figures}

Figure 1: Debris generated from 1990-2017 (million tons) ............................................... 1

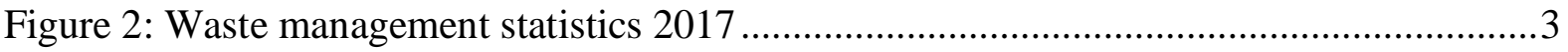

Figure 3:C\&D debris generated in 2014 by material and source ........................................ 7

Figure 4: Energy savings associated with recycling each material.....................................9

Figure 5: Avoided greenhouse gas associated with recycling each material .........................11

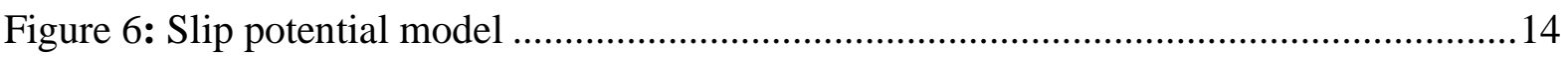

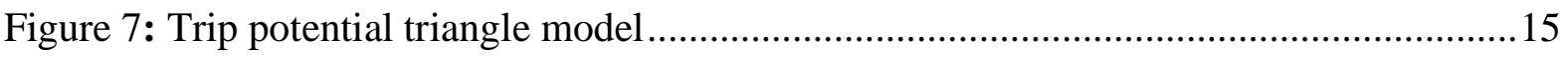

Figure 8: United states jobs by MSW management...................................................... 17



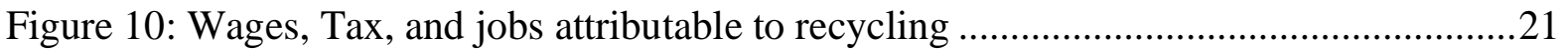

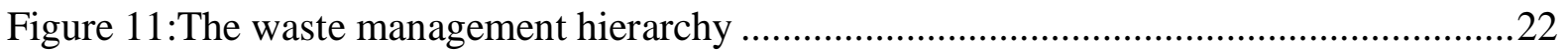

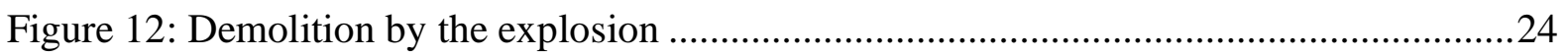

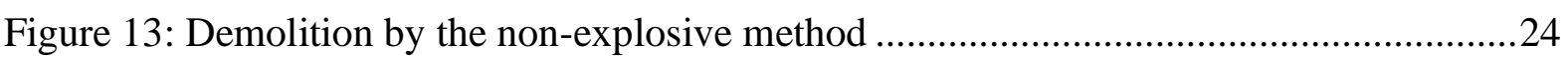

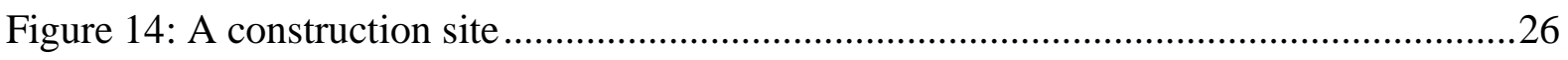

Figure 15: Contribution of construction and demolition phases to total 2012 C\&D ..............28

Figure 16: Contribution of construction and demolition phases to total 2013 C\&D ..............29

Figure 17: Contribution of construction and demolition phases to total $2014 \mathrm{C} \& \mathrm{D}$...............30

Figure 18: Contribution of construction and demolition phases to total 2015 C\&D ...............31

Figure 19: Contribution of construction and demolition phases to total $2017 \mathrm{C} \& \mathrm{D}$................32



Figure 21: Scrap drywall being loaded into a mobile grind ..............................................47

Figure 22:Drywall being ground using a mobile grinder..................................................48

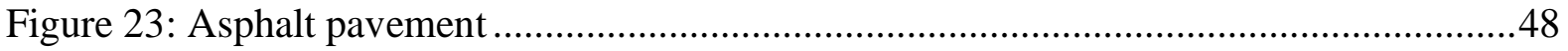

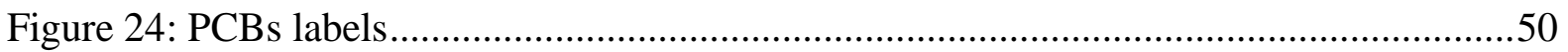

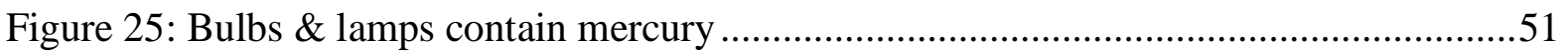

Figure 26:High-speed abrasive disc saws with filtered exhaust air ......................................54

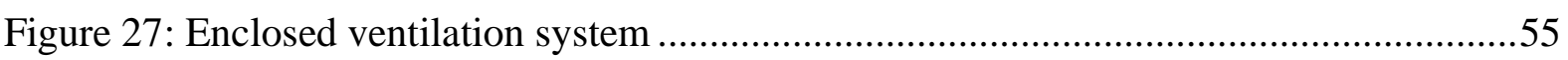




\section{Chapter 1. Introduction}

\subsection{Background}

A large amount of waste is produced by construction and demolition (C\&D) activities. Up to $80 \%$ of the solid waste stream is due to C\&D waste (Guyer, 2012). Common C\&D constituents wood products, Portland cement concrete, steel, brick, asphalt concrete and shingles, drywall and plaster, along with clay tiles. As per statistics, there has been an increase in debris generation due to C\&D waste as well as the renovation of buildings, bridges, and roads. According to the U.S. Environmental Protection Agency (EPA), debris generation from 1990 to 2017 increased 320\%, and the sharpest increase was 206\% between 2005 and 2012 . As shown in ( see Figure 1), 569 million tons of debris in 2017 were produced compared to 135 million tons in 1990. Debris generation from 2005 to 2012 due to C\&D waste accelerated at an alarming rate, making it an enormous problem that could not be ignored. Since 2012, the debris generation has increased at a slower rate of 7.3\% ("Advancing Sustainable Materials Management: Facts and Figures Report”) (see Figure 1).

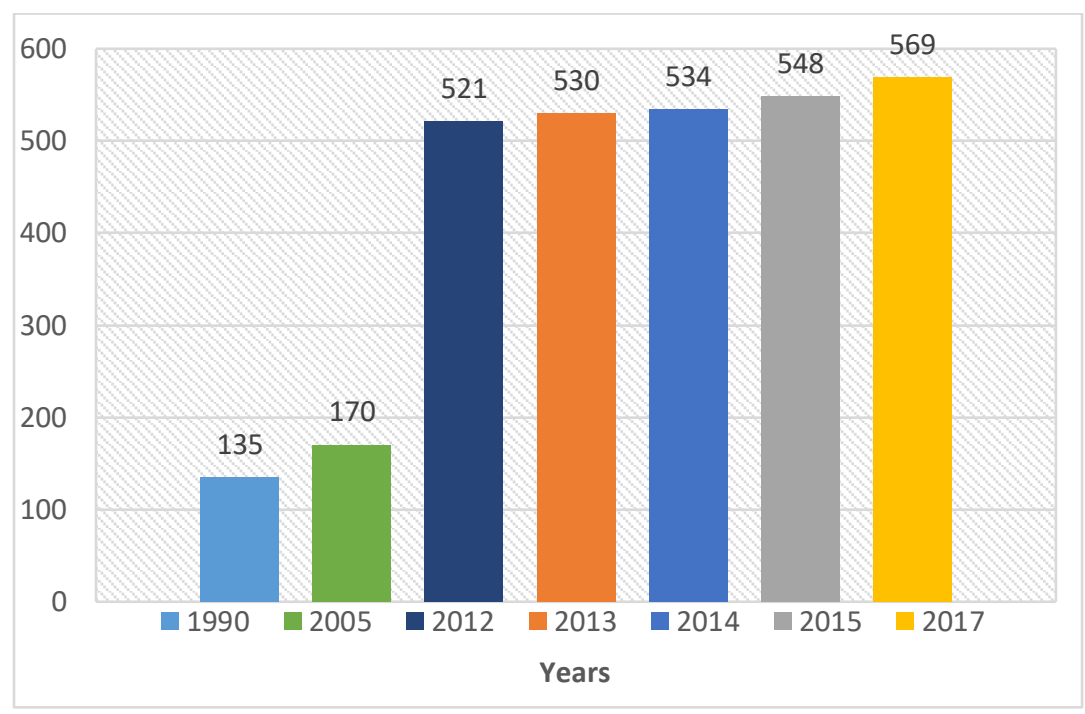

Figure 1: Debris generated from 1990-2017 (million tons)

Figure 1: "Advancing Sustainable Materials Management: Facts and Figures Report.” EPA, Environmental Protection Agency, 3 Apr. 2020, www.epa.gov/facts-and-figures-about-materials-waste-andrecycling/advancing-sustainable-materials-management. 
Construction waste management is a practice to recycle and reuse wastes for sustainable management of limited, exhaust resources (Napier, 2016). Recycling is the process of collecting and processing materials that would otherwise be thrown away as trash and turning them into new products. Using recycled materials eliminates the time spent waiting on new materials to be produced and delivered, thereby also reducing the cost of material production (Lennon, 2005). Recycling can be used in many different settings, including the construction industry. Although disposal is mandatory in some cases if the waste material is contaminated and not recyclable, most of the C\&D waste materials can be recycled to benefit the environment, safety, and economy (Cochran, 2007). For example, recycling and the reduction of C\&D materials conserve landfill space, reduces the environmental impact of producing new materials, creates jobs, and can reduce the overall expenses of construction projects by avoiding purchase/disposal costs ("Industrial and Construction and Demolition (C\&D) Landfills."). Also, Recycling improves the efficiency of a project by having a clean environment for workers on the site and by reusing the $C \& D$ waste. When the recycling and reusing processes take place on the construction site, costs such as transportation would be reduced, which also is very beneficial both to the contractor and the environment. On the other hand, disposal harms the environment and workers due to the pollutants created. Trash and disposal procedures also can be very expensive and dangerous for workers. Recycling is always more effective than disposing of C\&D waste materials (Lennon, 2005).

\subsection{Problems and needs}

There has been a huge increase in the amount of C\&D waste materials in the United States (U.S.). Between 1990 and 2017, the total increase in the debris was about 320\%, and that problem has continued to increase. Figure 2 shows how waste is managed in the U.S., and it is evident that recycling has not been fully embraced yet. Disposal in landfills remains the 
most used method to manage wastes ("Advancing Sustainable Materials Management: 2017 Fact Sheet."). Construction waste generation has taken up more space in landfills, and that impacts the environment, safety, and economy throughout the years, so it cannot be ignored any further. Furthermore, effective construction waste controls help to "conserve landfill space, reduce the environmental impact of producing new materials, create jobs, and can reduce overall building project expenses by avoiding purchase/disposal costs" ("Industrial and Construction and Demolition (C\&D) Landfills."). Also, the construction industry is among the industry sectors that generate a large number of waste materials. The waste materials generated by the construction industry generally are harmful to the environment and the health of humans. However, an in-depth discussion of the handling of C\&D waste materials and the current practices for effective controls was not found in the existing literature. Therefore, this research explores this topic more fully. Figure 2 shows how waste is managed in the U.S., indicating recycling has not been fully embraced yet. Disposal in landfills remains the most used method to manage wastes (“Advancing Sustainable Materials Management: 2017 Fact Sheet.”)



Figure 2: Waste management statistics 2017

Figure 2. "Management of MSW in the United States, 2017 ." EPA, Environmental Protection Agency, Nov. 2019, https://www.epa.gov/sites/production/files/201911/documents/2017_facts_and_figures_fact_sheet_final.pdf 


\subsection{Objective and scope}

The objective of this research is to explore current practices of construction waste management for effective controls in minimizing $\mathrm{C} \& \mathrm{D}$ waste and how they positively impact the environment, safety, and economy. This research discusses various types of C\&D waste materials; the advantages and disadvantages of the materials in the waste management process; the impacts of C\&D waste on the environment, safety, and the economy; and improved C\&D waste management practices. Construction waste materials have different lifespans range from short to long, and that what decides if the waste materials can be reused or recycled. Also, Construction waste has impacts on the environment, safety, and economy. The environment is affected by landfill and energy savings. Safety is affected by construction sites that contain waste on floors that can be harmful to workers, such as tripping accidents. The economy is affected by creating more job opportunities when the waste is recycled and decreased construction expenses. Construction waste management helps to control waste properly and get potential outcomes out of it. New construction and demolition sites have different recycling processes to reach high waste reduction performance. Construction sites generated a lot of waste material. Some of them are useful; some of them are harmful. Furthermore, it is important to recognize the usefulness of the harmful material to be able to deal with them in a proper way. Also, best practices for reducing construction waste are designing for adaptability, disassembly, reuse, or deconstructing buildings. These practices are provided by Environmental Protection Agency (EPA)) for safer recycling processes. Overall, these practices help to reduce the generation of construction waste. 


\section{Chapter 2. Construction waste impacts on the environment, safety, and economy}

\subsection{Landfill and energy saving impacts on the environment}

As C\&D wastes are landfilled, processed to renewed materials, or used as fuel substitutes, the environmental impacts from the wastes are derived from these practices. Depending on the practices, the environment can be affected positively or negatively. That is, the environment can be damaged by toxic gases and polluted leachates coming from landfill sites. The emission of carbon dioxide is well-known as the main cause of global warming. Proper recycling of waste materials can reduce the demands for limited natural resources and save the energy required to process raw materials. Raw materials extraction and transportation generates emissions that impact the environment negatively (Townsend, 2017).

\subsubsection{Landfill}

C\&D wastes landfilled can adversely affect the environment by generating foulsmelling gases. A prevalent example is hydrogen sulfide gas released from landfills. The waste of scrap drywalls is one of the main causes of generating this gas. When the drywall is disposed of in a C\&D landfill, naturally occurring bacteria can convert the sulfate extracted from the gypsum that makes up drywall into hydrogen sulfide, also referred to as $\mathrm{H}_{2} \mathrm{~S} . \mathrm{H}_{2} \mathrm{~S}$ is a gas with a strong rotten-egg odor and can be deadly at high concentrations and pose chronic health impacts at low concentrations (Townsend, 2017). Another negative environmental impact is leachates produced due to rainfalls percolating through the non-inert nature of C\&D debris. As a result, the groundwater bed can be affected by the chemicals leaching from the C\&D waste materials (Townsend, 2017).

Many C\&D waste materials in landfills with higher concentrations of sulfates and total dissolved solids (TDS) can be observed due to sulfate (Townsend, 2017). The permissible level 
of sulfate in water is $250 \mathrm{mg} / \mathrm{L}$ as per the U.S. Federal Secondary Drinking Water Standard (Townsend, 2017). The generation of methane gases due to C\&D wastes in landfills is another example to affect the environment adversely. According to an EPA report in 2012, 129.9 million metric tons (MMT) of carbon dioxide equivalent $(\mathrm{CO} 2 \mathrm{e})$ emissions were produced. In the report was noted that 13 MMT CO2e were produced from 26,681 miles of pipeline distributions, and that takes more than $10 \%$ of the total methane emissions from the natural gas system in the United States ("Improvements Needed in EPA Efforts to Address Methane Emissions From Natural Gas Distribution Pipelines.”).

Various environmental issues can be addressed while recycling C\&D waste materials. Proper recycling of this waste into, for example, agricultural products or new drywalls reduces the chances of forming toxic gases. Landfill operations should be dealt with extra care while working in confined space or excavation activities. Some C\&D debris landfill operators have been required to install a gas collection and recovery systems, and others have resorted to placing odor masking agents around their sites. In the Vancouver area, gypsum drywall was banned from disposal in landfills due to odor problems(Townsend, 2017). Therefore, controlling toxic gases through proper recycling can help save the continual maintenance and operational costs of landfills. Recycling C\&D waste materials decrease various environmental concerns by reducing the volume of debris being buried in landfills. As shown in( See Figure 3), roads and bridges were the principal sources generating C\&D debris in 2014 , followed by buildings and other structures. The main material types of debris from roads and bridges were the concrete and asphalt concrete. On the other hand, the wastes of the buildings were composed of various materials such as concretes, wood products, drywall and plasters, brick and clay tiles, asphalt shingles, and steel. Table 1 shows the recycled materials such as mixed C\&D, bulk aggregate, and reclaimed asphalt pavement (RAP) in the unit of million tons in 
2014 (3). Considering the bulk densities of these materials (e.g., 1,200 pounds per cubic yard (pcy) for mixed C\&D; 2,200 pcy for bulk aggregate; and 2,000 pcy for RAP) and $50 \mathrm{ft}$. in a landfill depth, the recycling process was estimated to save about 5,534 acres of the landfill areas (Townsend, 2017).

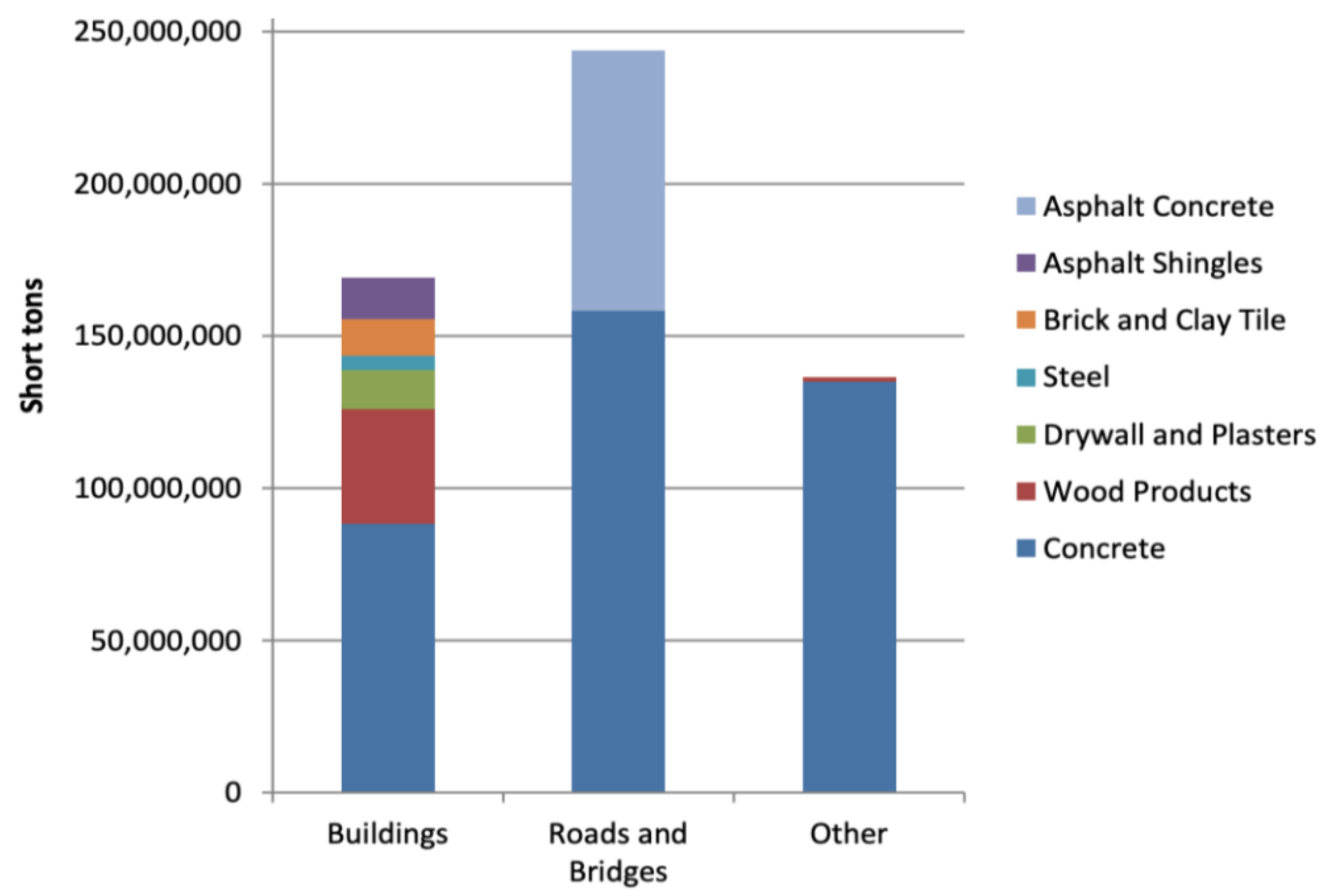

Figure 3:C\&D debris generated in 2014 by material and source

Figure 3. "C\&D Debris Generated in 2014 by Material and Source." EPA, Environmental Protection Agency, Sept. 2018, https://www.epa.gov/sites/production/files/2018-09/documents/construction and_demolition_debris_generation_in_the_united_states_2015_final.pdf

\begin{tabular}{ccc}
\hline Recycled Material & Million Tons & Acres Saved \\
\hline Mixed C\&D & 63.4 & 1,310 \\
\hline Bulk Aggregate & 290 & 3,277 \\
\hline RAP & 76.3 & 947 \\
\hline Total & 430 & 5534 \\
\hline
\end{tabular}

Table 1: Millions of tons recycled of each category and the corresponding

Source: Townsend, Timothy G., and Anshassi, Malak. "Millions of tons recycled of each category and the corresponding." CDRA, 1 Apr. 2017, https://www.nrcne.org/wp-content/uploads/2019/12/cdra_benefits_of_cd recycling final revised 2017.pdf 


\subsubsection{Energy savings}

A large amount of energy is saved during the recycling processes because the extraction process has a low energy requirement. A typical example is the re-utilization of steel obtained from $\mathrm{C} \& \mathrm{D}$ aggregates that requires much less energy as compared to the maiden process. Recycling concrete can save one billion gallons of gasoline, equivalent to removing about 1 million cars from roads (Cochran, 2007). Also, energy savings can be obtained from the combustion of $\mathrm{C} \& \mathrm{D}$ debris and the avoidance of transporting waste materials. Table 2 shows the energy savings in a million BTU of the C\&D materials. Figure 4 is presented for a graphical comparison of the energy saving in the C\&D waste materials. In 2014, a total of 682 million BTUs (British thermal unit; equivalent to 117 million barrels of oil) were save by recycling in the U.S. According to the CDRA, these energy savings are equivalent to:

- 10.25 million Passenger vehicles driven for one year

- 2.20 million Garbage trucks of waste recycled instead of landfilled

- 5.46 billion Gallons of gasoline consumed

- 5.12 million Homes energy use for one year

- $\quad 12,260$ Wind turbines installed

- $\quad 1.72$ billion Incandescent lamps switched to LEDs

- 14.1 Coal-fired power plants in one year

- 1.25 billion Tree seedlings grown for 10 years

- 45.9 million acres of U.S. forests in one year. (Townsend, 2017) 


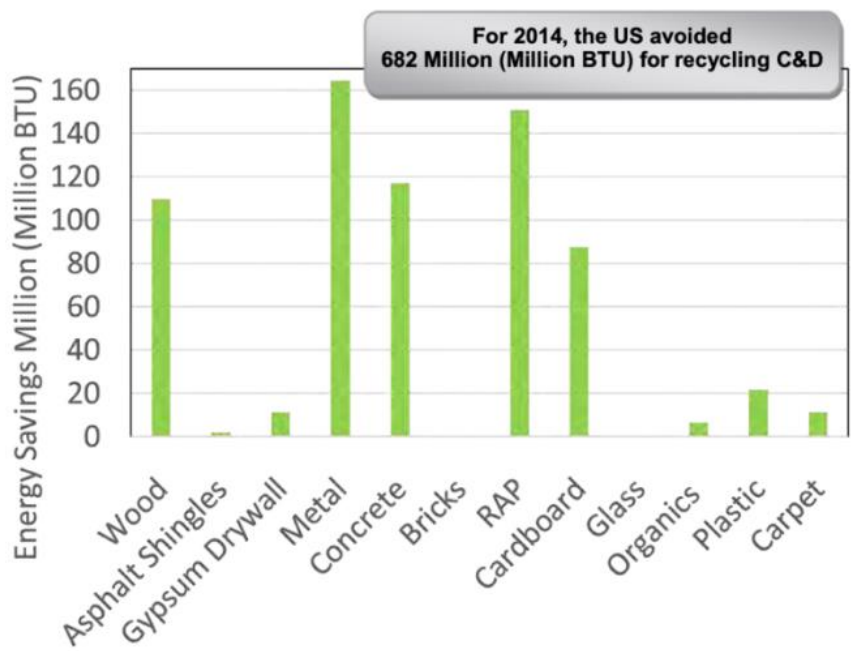

Figure 4: Energy savings associated with recycling each material

Figure 4. Townsend, Timothy G., and Anshassi, Malak. "Energy savings associated with recycling each material." CDRA, 1 Apr. 2017, www.nrcne.org/wp-content/uploads/2019/12/cdra_benefits_of_cd_recycling final_revised_2017.pdf.

\begin{tabular}{cc}
\hline Material & Energy Savings Million (Million BTU) \\
\hline Wood & 109 \\
\hline Asphalt Shingles & 1.91 \\
\hline Gypsum Drywall & 11.2 \\
\hline Metal & 164 \\
\hline Concrete & 117 \\
\hline Bricks & 0.67 \\
\hline RAP & 150 \\
\hline Cardboard & 87.5 \\
\hline Glass & 0.4 \\
\hline Organics & 6.25 \\
\hline Plastic & 21.7 \\
\hline Carpet & 11.3 \\
\hline Total & 682 \\
\hline
\end{tabular}

Table 2: Energy savings of each $C \& D$ material

Source: Townsend, Timothy G., and Anshassi, Malak. "Energy savings of each C\&D material using WARM factors." CDRA, 1 Apr. 2017, www.nrcne.org/wp-content/uploads/2019/12/cdra_benefits_of_cd_ recycling_final_revised_2017.pdf 
During the recycling process, less energy is used as compared to the process of producing new materials, and as a result, the emission of greenhouse gases (GHG) is also reduced. When recouped $C \& D$ materials are utilized to substitute virgin materials, GHG creation is generally diminished, which brings a net ecological advantage. Waste Reduction Model (WARM) emission factors represent net environmental benefits such as GHG emission reduction that can be obtained from recycling or combusting $C \& D$ wastes compared to landfilling. The emission factor of each C\&D material is multiplied by the recycled quantity of the waste material to estimate the annual net metric tons of CO2 (MTCO2E) avoided. Table 3 includes the MTCO2E avoided in a million tons for various materials, which is also illustrated in Figure 5 for visual comparison. Recycling or combusting is effective in avoiding MTCO2E for most of the materials. A total of 43.9 million MTCO2E avoided is equivalent to:

- 9.27 million Passenger vehicles driven for one year

- 1.99 million Garbage trucks of waste recycled instead of landfilled

- 4.94 billion gallons of gasoline consumed

- 4.64 million Homes energy use for one year

- 11,093 Wind turbines installed

- $\quad 1.56$ billion Incandescent lamps switched to LEDs

- $\quad$ 12.8 Coal-fired power plants in one year

- 1.13 billion Tree seedlings grown for 10 years

- 41.6 million acres of U.S. forests in one year. (Townsend, 2017) 


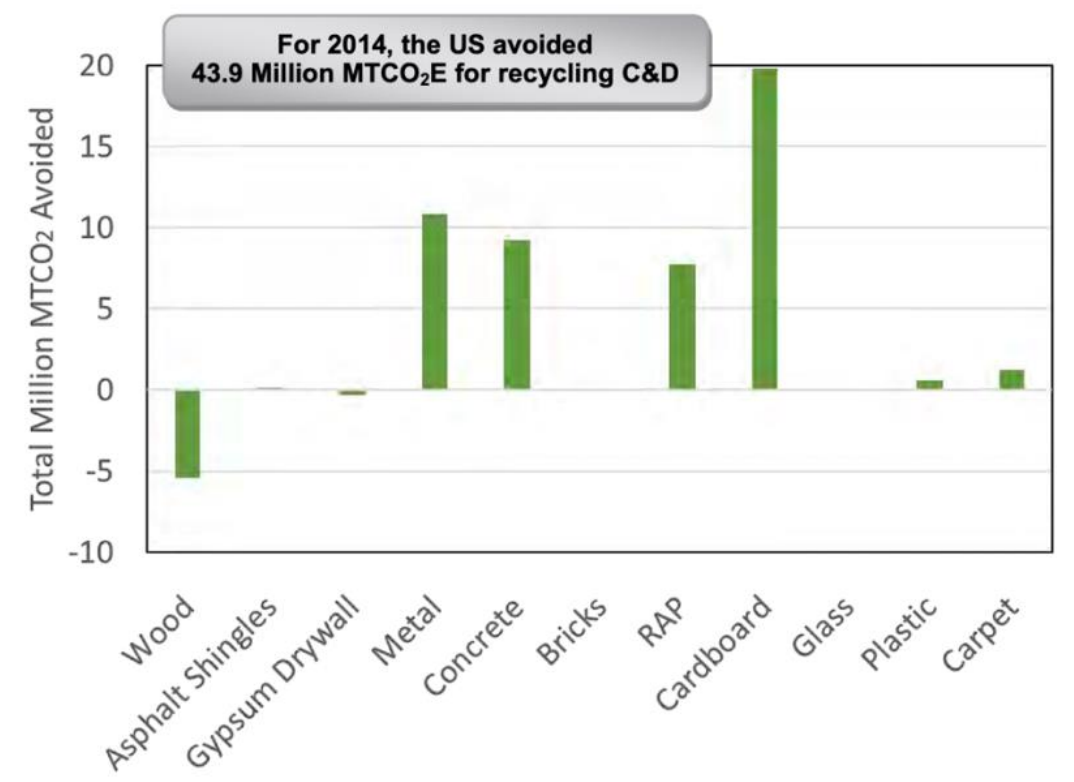

Figure 5: Avoided greenhouse gas associated with recycling each material

Figure 5. Townsend, Timothy G., and Anshassi, Malak. "Avoided greenhouse gas associated with recycling each material." CDRA, 1 Apr. 2017, www.nrcne.org/wp-content/uploads/2019/12/cdra benefits of cd recycling final_revised_2017.pdf

\begin{tabular}{cc}
\hline Material & Total Million MTCO2E Avoided \\
\hline Wood & -5.41 \\
\hline Asphalt Shingles & 0.14 \\
\hline Gypsum Drywall & -0.35 \\
\hline Metal & 10.8 \\
\hline Concrete & 9.24 \\
\hline Bricks & 0.05 \\
\hline RAP & 7.76 \\
\hline Cardboard & 19.8 \\
\hline Glass & 0.05 \\
\hline Plastic & 0.58 \\
\hline Carpet & 1.24 \\
\hline Total & 43.9
\end{tabular}

Table 3: Metric tons of CO2 equivalent avoided of each C\&D material

Source: Townsend, Timothy G., and Anshassi, Malak. "Metric Tons of CO2 Equivalent avoided of each C\&D material." CDRA, 1 Apr. 2017, www.nrcne.org/wp-content/uploads/2019/12/cdra_benefits_of_cd_recycling final_revised_2017.pdf 


\subsection{Safety}

C\&D wastes on construction sites are often seen as hazards. With the huge amount of wastes being generated every year, construction sites can be unsafe to workers if they are not well-maintained through recycling. The waste materials collected in one place can prevent construction workers from being hurt and make construction sites organized (Lennon, 2005). The most common types of hazards in recycling C\&D wastes are accidents related to traffic safety, loading/unloading, and slips/trips.

\subsubsection{Traffic safety, loading, and unloading}

Traffic accidents occur on construction sites while transporting C\&D waste materials. The Safety and Health Information of the Occupational Safety and Health Administration (OSHA) provides the basic safety guidelines to avoid crushing hazards connected to dumpsters and rear-loading trash trucks ("Recycling: Traffic Safety, Loading and Unloading."). When these guidelines are followed carefully, many accidents can be avoided. It should be noted that the steps in the guidelines are suggested for recycling wastes in general. Thus, the steps are applicable for construction sites to assist in safer transporting procedures to separate and collect C\&D wastes. Then, transporting and loading/unloading procedures in construction sites as shown:

1. The driver must always check the vehicle in detail to assure that all the accessories and parts are working properly. These checks must be made before and after each shift to make sure that no wear and tear of the vehicle results in any potentially harmful event.

2. The vehicles must be driven on roads that are safely constructed. These roads must also be well maintained for the avoidance of any dangerous outcome. 
3. The driver must take extra precautions while reversing the vehicle. In case of an obstructed rear view, the drive must not drive in the reverse gear.

4. Before dumbing or lifting any devices it must be confirmed that all the personnel is in the clear.

5. The vehicles and equipment should be set on parking breaks after being parked. If the parked surface is an inclination, then choke the wheels.

6. Be mindful of the vehicle's or equipment's load capacity and do not exceed it.

7. The braking system must be up to date and regular upgrades must be made to all other safety features as well.

8. Workers must wear warning clothes such as colored vests. It should be observed that they are visible from all levels of lights. They must wear reflective clothes during night time.

9. The vehicle should not carry unnecessary personnel.

10. Seat belts must meet all the safety standards. The seat belt should be worn at all times except for equipment that has a stand-up operation.

11. All controls should be left at neutral when the equipment is not in use. The equipment such as bulldozer should be lowered or blocked when not in use (“Recycling: Traffic Safety, Loading and Unloading.").

\subsubsection{Slips \& trips on site}

Constructions sites are more vulnerable to slip and trip accidents due to objects or wastes left behind on floors or hallways. The United Kingdom (UK) government agency, the Health and Safety Executive (HSE), presented the slip potential model (see Figure 6) that helps reduce slip accidents and suggests actions to prevent them ("Causes and Prevention."). The model suggests a total of six elements contributing to slip accidents. At least one of these 
elements may have an impact on any slip accidents. The cleaning and contamination elements are presented for further details because of their high impact on slip accidents in the following (see Figure 6).

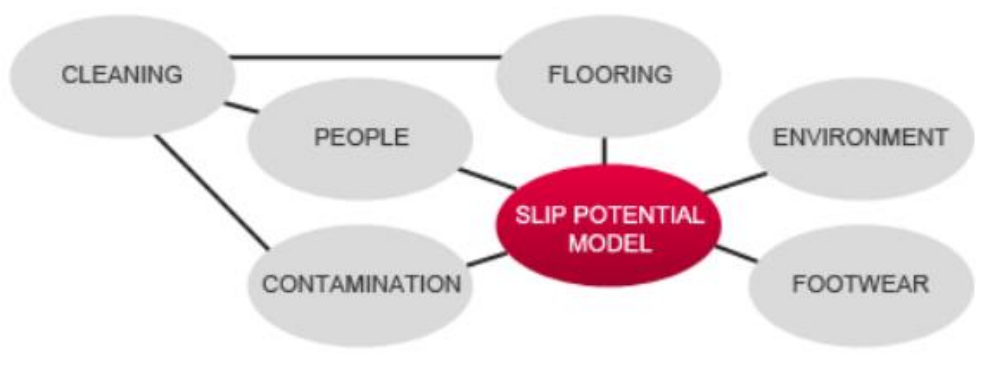

Figure 6: Slip potential model

Figure 6. "Trip Potential Triangle." HSE, Health and Safety Executive, 2020, www.hse.gov.uk/slips/preventing.htm.

\section{Cleaning:}

Cleaning is significantly effective in avoiding slip risks. Cleaning often deals with the contamination that would otherwise cause slips. At cleaning time, slip accidents can occur, and some basic steps should be taken while cleaning as follows:

1. Chose less busy hours

2. Don't allow access to the place while it is still wet

3. Sections cleaning strategy must be used so that there is a dry place to walk on

4. Always place warning signs at the site if wet

5. Make sure the cleaning equipment is well maintained to assure effectiveness.

6. Apply a dry mob after cleaning to minimize drying time ("Cleaning.").

\section{Contamination:}

Individuals seldom slip on a clean, dry floor. Contaminants on floors such as downpour water, oil, and dust are associated with practically all slip accidents. In the case of smooth surfaces such as standard vinyl, tiles, or varnished wood, even a small measure of 
contamination can be a genuine slip issue. This problem can simply be controlled by identifying the sources of contamination. The contamination is possible coming from spills, leaks, overflow, cleaning activity, run-off, and footwear. After the sources are identified, it is essential to stop the contamination from reaching the floor. The methods to stop the contamination include guards, drip trays, lids, review working practices, and entrance matting. If stopping the contamination is not possible, other control measures then should be employed.

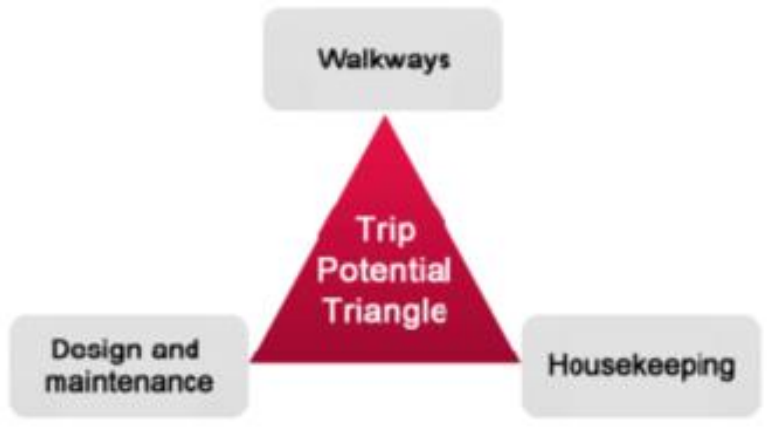

Figure 7: Trip potential triangle model

Figure 7. "Trip Potential Triangle.” HSE, Health and Safety Executive, 2020, www.hse.gov.uk/slips/preventing.htm.

The UK - HSE also presents the trip potential triangle (see Figure 7) that consists of three elements, such as walkways, housekeeping, and design and maintenance, as shown in Figure 7. Deterrents in walkways are responsible for the majority of tripping accidents. Uneven surfaces are also reasons for trip-related accidents. All three elements are required to work together to prevent tripping accidents effectively. As construction sites are very likely full of walkway obstructions and uneven surface conditions, there should be more attention to considering these elements. The safety of walkways can be obtained by checking whether the walkways are in use or suitable for use in the right place. For example, walkways that possess any potential hazards to workers due to tasks taking place should be avoided. Housekeeping is required to keep walkways clear to any obstructions. Design and maintenance are required to provide and maintain safe walkway conditions for workers. For example, walkways suitable to 
use are in the conditions of a sufficient number of lighting facilities, slopes and steps clearly visible, and wide enough.

\subsection{Economy}

The revitalization of the recycling industry brings economic benefits from creating job opportunities for unemployed individuals (Abdul-Shafy and Mansour, 2018). Recycling of C\&D waste materials has various positive effects on the overall economy through the reduction of costs and the increase in personal incomes and the tax revenues of governments.

\subsubsection{Job creation}

Recycling C\&D wastes, which consists of procedures for off-loading, processing, and segregating incoming materials as well as transporting recycled products, is more laborintensive than landfilling (Townsend, 2017). Jobs related to recycling C\&D wastes include: 1) gathering, handling, and preparing the materials, 2) making new items, and 3) reusing and re-manufacturing. The disposed wastes are gathered and brought to facilities where they are arranged and sold off to business sectors and different markets. The waste materials recoverable, such as papers, plants, metals, and plastics, are processed into recycled feedstocks. Some of the wastes are arranged and repaired for reuse (Bailey, 2016).

Figure 8 shows the jobs by municipal solid waste (MSW) based on the 2008 data (Bailey, 2016). The jobs for manufacturing \& composting (45\%) and recycling collection (37\%) together take more than $80 \%$ of the MSW management related jobs in the U.S. By increasing the rate of reusing wastes to $75 \%$ by 2030 ; it is estimated that the U.S. can generate 1.1 million new jobs. The occupations from reusing C\&D wastes had been growing by $7 \%$ every year during 2000 - 2007 in the European Union (E.U.). The E.U. can add 560,000 new 
jobs by reusing $70 \%$ of disposals. The E.U. research shows that the jobs for reusing disposals pay higher salaries than landfills and incinerators. Around the world, it is estimated that around 15-20 million waste pickers make a living through scavenging discards. The United Nations (U.N.) estimates that sustainable development initiatives, including recycling, could create 60 million new openings (Bailey, 2016).

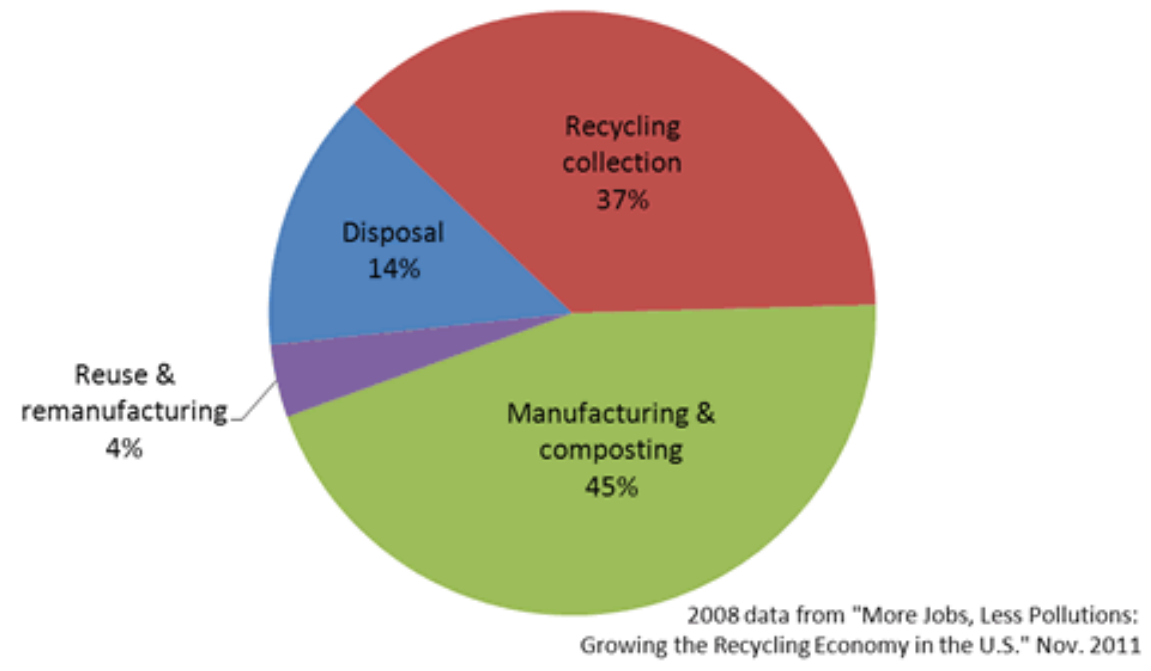

Figure 8: United states jobs by MSW management

Figure 8. Bailey, Kate. "United States jobs by MSW management." Ecocycle, Eco-Cycle, Inc, 2016, www.ecocycle.org/zerowaste/jobs.

\begin{tabular}{cccc}
\hline $\begin{array}{c}\text { Recycled } \\
\text { Material }\end{array}$ & $\begin{array}{c}\text { Million } \\
\text { Tons }\end{array}$ & $\begin{array}{c}\text { Jobs per MT of Annual C\&D } \\
\text { Recycled }\end{array}$ & $\begin{array}{c}\text { Thousands Jobs } \\
\text { Produced }\end{array}$ \\
\hline Mixed C\&D & 63.4 & 233 & 14.8 \\
\hline Bulk Aggregate & 290 & 45 & 13.3 \\
\hline Total & 430 & & 27.9 \\
\hline
\end{tabular}

Table 4: Millions of tons recycled in each category and the corresponding jobs

Source: Townsend, Timothy G., and Malak Anshassi. "Millions of tons recycled of each category and the corresponding jobs.", CDRA, 1 Apr. 2017, https://nrcne.org/wp-content/uploads/2019/12/cdra_benefits_of_cd_recycling final_revised_2017.pdf

As per the survey conducted by the National Asphalt Pavement Association (NAPA) in 2014 , approximately 28,000 jobs were produced for the needs for recycling waste materials 
such as bulk aggregate and mixed C\&D, as shown in Table 4. That is, a million tons of the wastes recycled created 79.5 jobs annually. The mixed C\&D are generated from building construction, renovation, and demolition activities and include recyclable and non-recyclable waste materials (Townsend, 2017).

\subsubsection{Overall economy}

The economy would suffer from resource exhaustion without recycling (Grosse, 2020). Recycling always resonates well with the amount of waste at the site. The more wastes are recycled, the less raw materials are used. Construction firms can save much money by recouping and selling scraps, which generates additional processing expenses, otherwise. The promotion of collecting $C \& D$ wastes on sites needs jobs for dropping off and picking up waste storage drums. Such job creations specifically boost the local economies benefiting the local construction industry and communities. If $\mathrm{C} \& \mathrm{D}$ materials are not properly recycled, they will have several consequences. This ranges from much money that would be spent to buy more products to use substandard materials that have been gotten from inadequate recycling. Figure 9 shows that iron recycling helps the global economy by increasing the growth rate of global production by more than $3 \%$. 


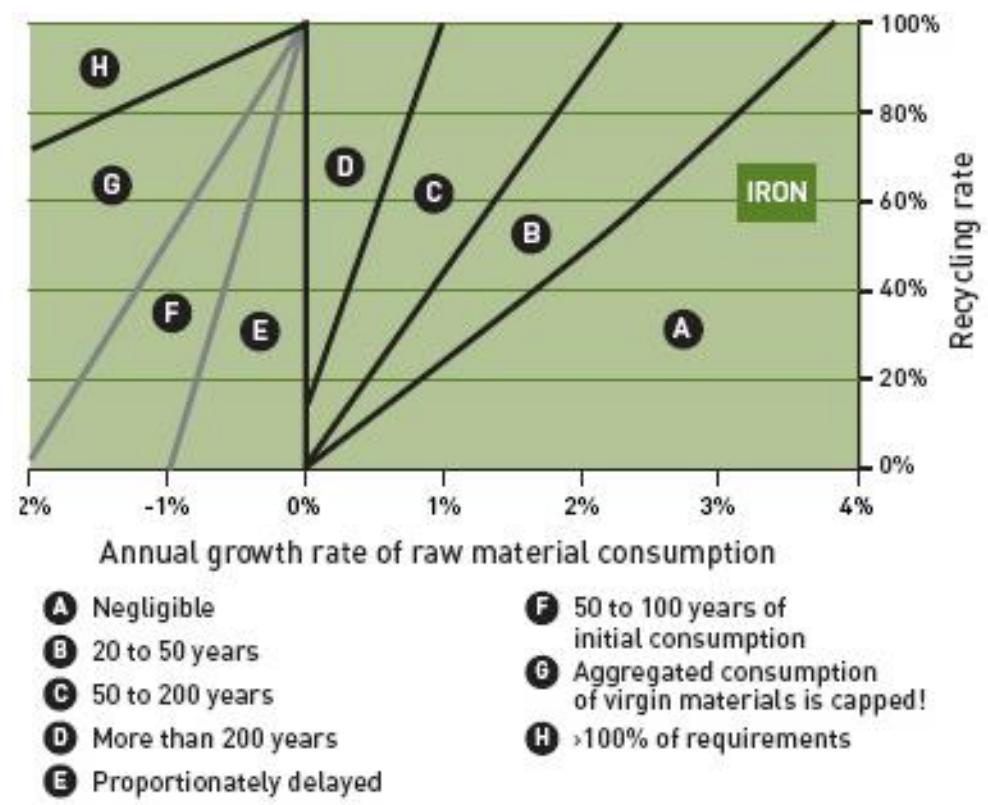

Figure 9: Overall effect on the economy

Figures 9. François Grosse, "Map of the impact of recycling on expected depletion dates", S.A.P.I.EN.S [Online], 3.1 | 2010, Online since 10 February 2010, connection on 06 November 2020. URL: http://journals.openedition.org/sapiens/906

As C\&D wastes left on construction sites threaten workers' safety, recycling can effectively eliminate the potential risks, consequently positively impacting the overall economy. For instance, the C\&D debris such as steel or glass materials scattered around work sites are likely to hurt workers and pedestrians. Such accidents could be avoidable if the waste were managed well to generate unnecessary costs weighing on individuals, companies, or governments through insurance and medical covers. Furthermore, at the time of medical attention, the workers are not productive, negatively impacting the economy.

Most of the economic benefits can be derived from the increase in the number of jobs created due to the need for recycling activities. According to the report released by EPA, the recycling industry in 2007 created a total of 757,325 new jobs that accounted for $0.52 \%$ of the U.S. economy. The report indicates that 1,000 tons of recycled materials contributed to creating 
1.57 jobs that provided the cash inflows to the workers of $\$ 76,000$ in wages and the governments of $\$ 14,101$ in tax revenues. As a whole, the workers in the job earned about $\$ 36.6$ billion in wages, paying about $\$ 6.7$ billion as the tax. The portion of the tax revenue was $0.9 \%$ of the U.S. total revenues in 2007. In general, tax revenue is the primary source of governments to invest in various sectors, including economic benefits. ("Advancing Sustainable Materials Management: 2016 Recycling Economic Information (REI) Report.”). Table 5 summarizes all the numbers and percentages aforementioned. Figure 10 shows the 2007 statistics regarding wages, taxes, and jobs attributable to different recycling categories. Assuming that the trend continues today, recycling $\mathrm{C} \& \mathrm{D}$ waste materials play a vital role in increasing personal incomes and sharing the U.S. economic outputs compared to others.

\begin{tabular}{crc}
\hline Metric & \multicolumn{1}{c}{ Total } & Tax Revenue Percentage \\
\hline Jobs & 757,325 & $0.52 \%$ \\
\hline Wages & $\$ 36,636,597,000$ & $0.62 \%$ \\
\hline Tax Revenue & $\$ 6,795,244,000$ & $0.9 \%$ \\
\hline
\end{tabular}

Table 5: Jobs, wages, and tax revenue percentages in 2007

Source: "2016 REI Report Estimates of Contributions of Recycling to U.S. Economic Activity/Quantity and Value Contribution.” EPA, Environmental Protection Agency, Oct. 2016, www.epa.gov/sites/production/files/201705/documents/final 2016 rei report.pdf. 


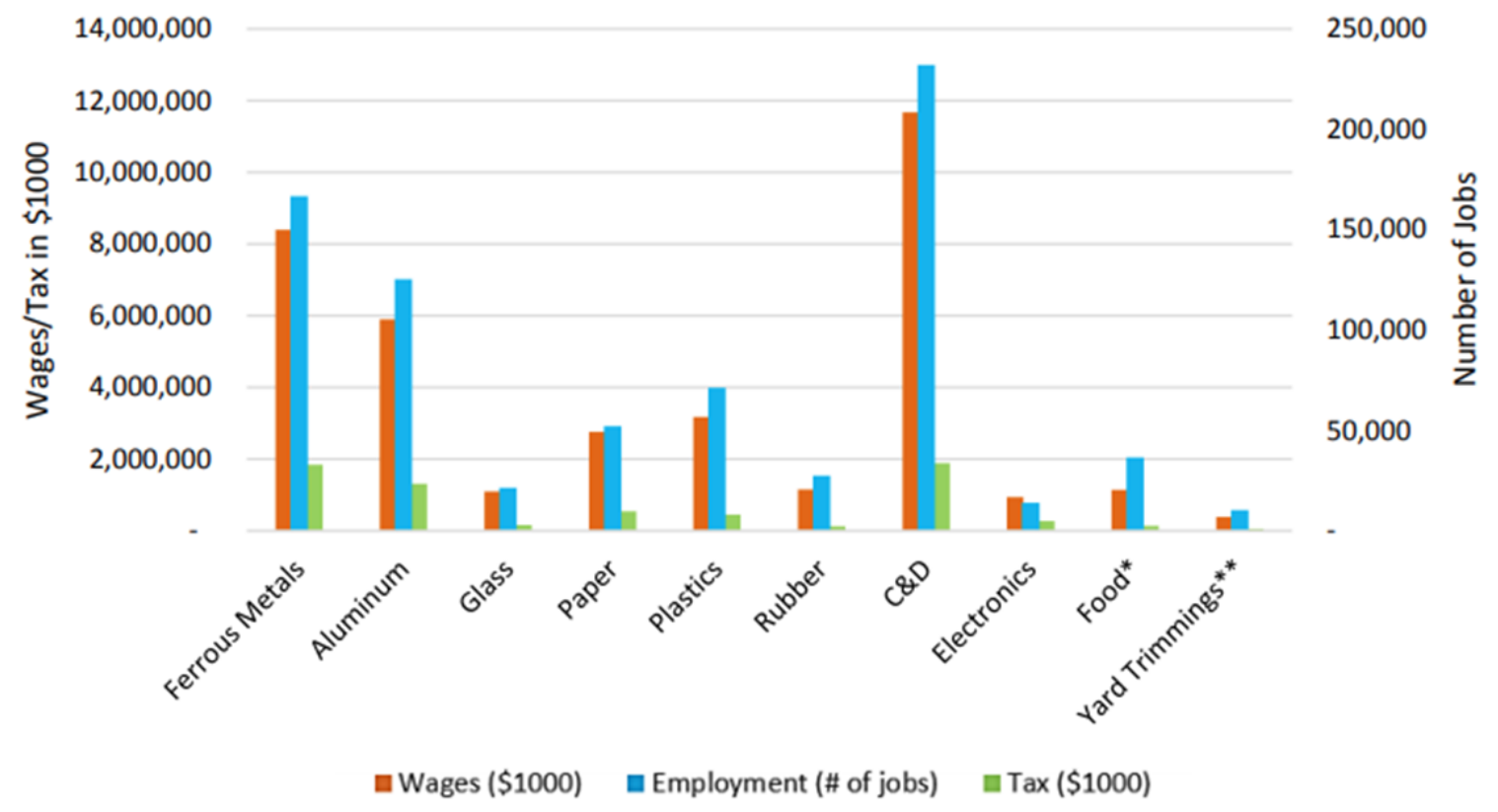

Figure 10: Wages, Tax, and jobs attributable to recycling

Figure 10. "Wages, Tax, and jobs attributable to recycling." $E P A$, Environmental Protection Agency, Oct. 2016, www.epa.gov/sites/production/files/2017 05/documents/final_2016rei_ report.pdf. 


\section{Chapter 3. Construction waste management}

Construction waste management has different processes for different types of construction projects. These different processes are followed depending on whether the site is a new construction or demolition site. These processes aim to efficiently utilize the waste generated out of the C\&D. It has been proven statistically, throughout history, that demolition sites have had more debris generation than construction sites. The debris generation out of these demolition sites stood as high as $95 \%$ more than the new construction sites. This means that demolition sites will have more recoverable material than new construction sites. Hence, different processes are used at demolition sites than that used at construction sites. Furthermore, the EPA also provides different processes and practices for the new construction sites and different processes and practices for the demolition sites to efficiently minimize and control waste.

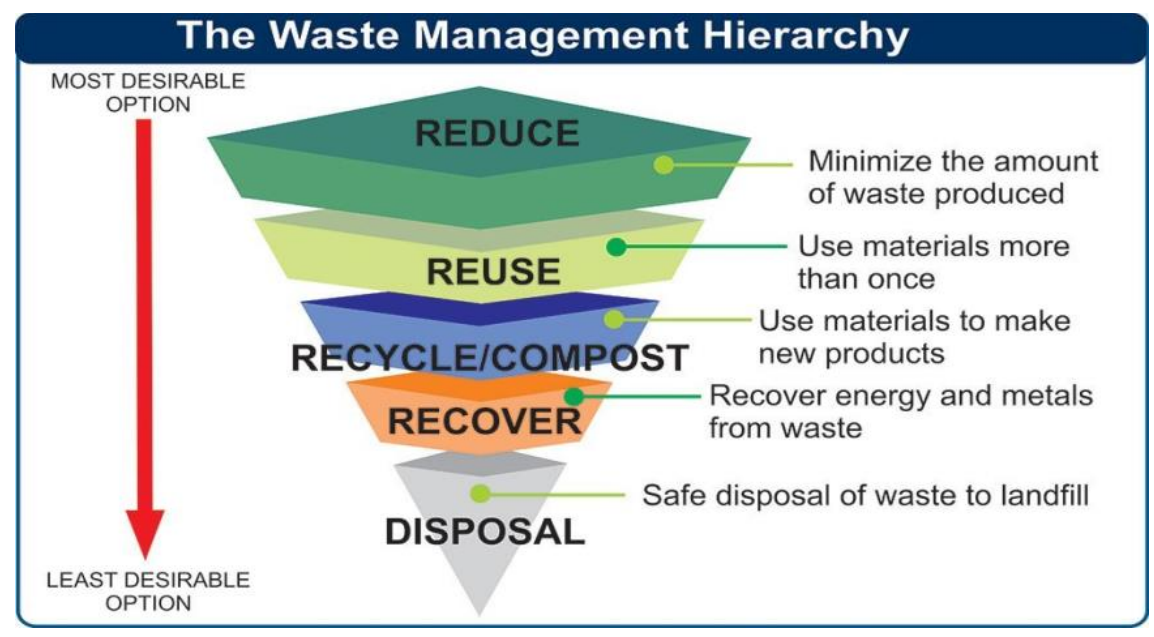

Figure 11:The waste management hierarchy

Figure 11. "The Waste Management Hierarchy." USGBC West Michigan, USGBC West Michigan Chapter, 12 Sept. 2017, www.usgbcwm.org/no-timeto-waste-waste-diversion-in-construction/.

The main objective of the construction waste management could be described and illustrated in a hierarchy as shown (see Figure 11) below that follows these specific steps. These steps go from reducing the waste to reusing it on site. If the waste is not reusable or 
recyclable on-site, it should be recycled off-site for further use for construction projects or societies. After the recycling process, it is important to recover the energy from the recycled material. Finally, if the waste is not recyclable and recoverable, it has to be disposed of so that there is no further damage to the environment, public safety, and economy.

Waste generated from a construction project should be as low as possible. The waste that is produced by mishandling, breakage, poor planning, contamination, or error should be recycled, salvaged, or reused economically into other useful products. The cost of the project can also be reduced by minimizing the incineration and landfilling of the waste. A construction management plan should be developed in a way that it can cover the utilization of C\&D debris up to $95 \%$ by weight. Globally, Leadership in Energy and Environmental Design (LEED) is the most widely used green buildings rating system.

\subsection{Construction and demolition $(C \& D)$ waste}

Construction and demolition waste make up a large portion of the world's total landfill waste. It is the main part of industrial waste. The waste comprises many different materials and comprises an enormous variety of building materials, and even incorporates modest quantities of hazardous substances. This poses a huge problem in many countries. The processing of this waste is becoming more and more relevant in most of the developed nations. The waste out of a worksite should be included in the project plan rather than an afterthought or add on. An Auckland study has shown that the C\&D waste by weight is made up of $5 \%$ metal, $13 \%$ plasterboard, 20\% timber, 5\% packaging, and 45\% others (Lamont, 2019). This research also highlighted that by simple sorting of this waste materials, half of it could be diverted to clean fill. 


\subsubsection{Demolition projects}

Demolishers disassemble structures utilizing pre-arranged and controlled strategies.

Demolition of a building is the way toward disassembling or decimating a structure after its life of usefulness. This process may be carried out by two methods, explosive and nonexplosive demolition (“Demolition by Explosive .”) (see Figure 12 and Figure 13)

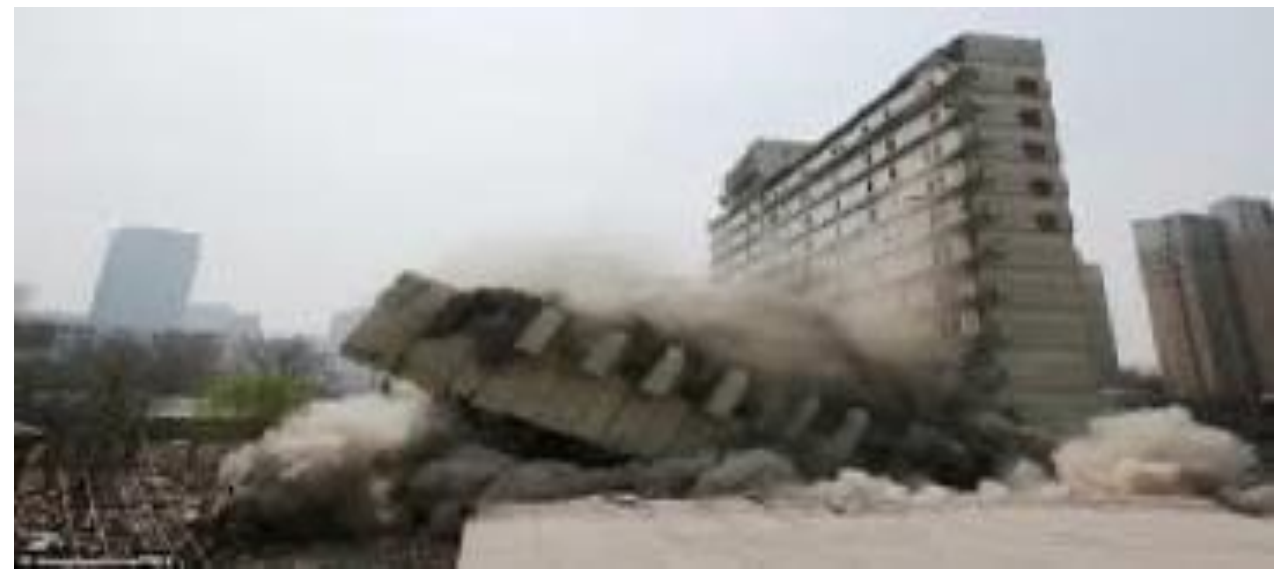

Figure 12: Demolition by the explosion

Figure 12. "Demolition Methods and Process for Building Structures." The Constructor, The Constructor Civil Engineering Home, 27 Oct. 2016, www.theconstructor.org/structures/demolition-methods-process-buildingsstructures/13941/.

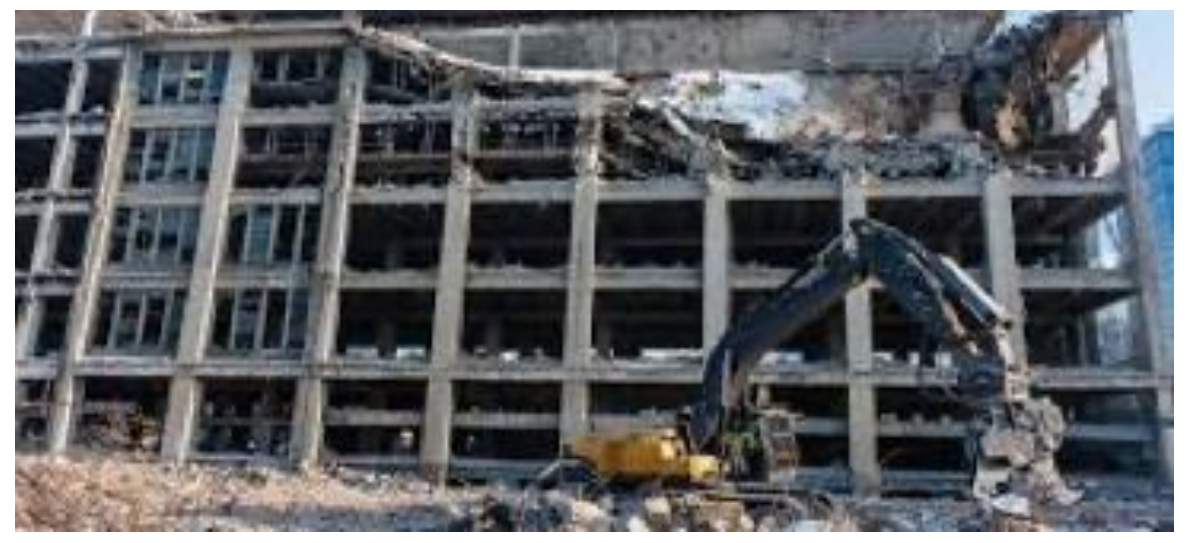

Figure 13: Demolition by the non-explosive method

Figure 13. Rodriguez, Juan. "Demolition by Non-Explosive Method." The Balance Small Business, The Balance Small Business, 14 June 2019, www.thebalancesmb.com/ways-to-demolish-buildings-844420. 


\section{General recycling procedures in demolition site:}

Before the demolition of the structure, the initial step is to evacuate available and reusable materials. After the structure is crushed, more pieces of material can be gathered from the rubble. These can be reused once contaminants and non-recyclable materials are evacuated. Nowadays, many non-residential buildings contain steel in their structure, and almost all of this steel may be recycled. Many structural parts can be reused where markets exist. Cement and rubble can be reused into new concrete products. Wood can be reused into more wood items such as furnishings, as well as mulch, manure, and different items. Architectural glass is among the most remarkable structural items being used today. It is also widely used in making "transparent" buildings. When taken out from its assembled setting, glass is, in principle, a highly reusable material and limitlessly recyclable to original quality. The on-site recycling facility can be established by simply planning. This will help in reusing and recycling most of the materials. Containers for specific materials can be placed on-site for effective separation of a specific kind of material as well ("Recycle Construction Waste to Save Money and the Environment.").

\subsubsection{Construction projects}

The term construction is used for an organized effort to build a structure. These structures are often referred to as buildings. In the fields of structural designing and engineering, development projects include the procedure that comprises creating a foundation or building. These are the methods and industries associated with the get-together and erection of structures ("Understanding Construction Projects"). This is one of the oldest human practices meant to provide shelter to human beings. These structures may be used for all sorts of things ranging from entertainment to sheltering (see Figure 14). 


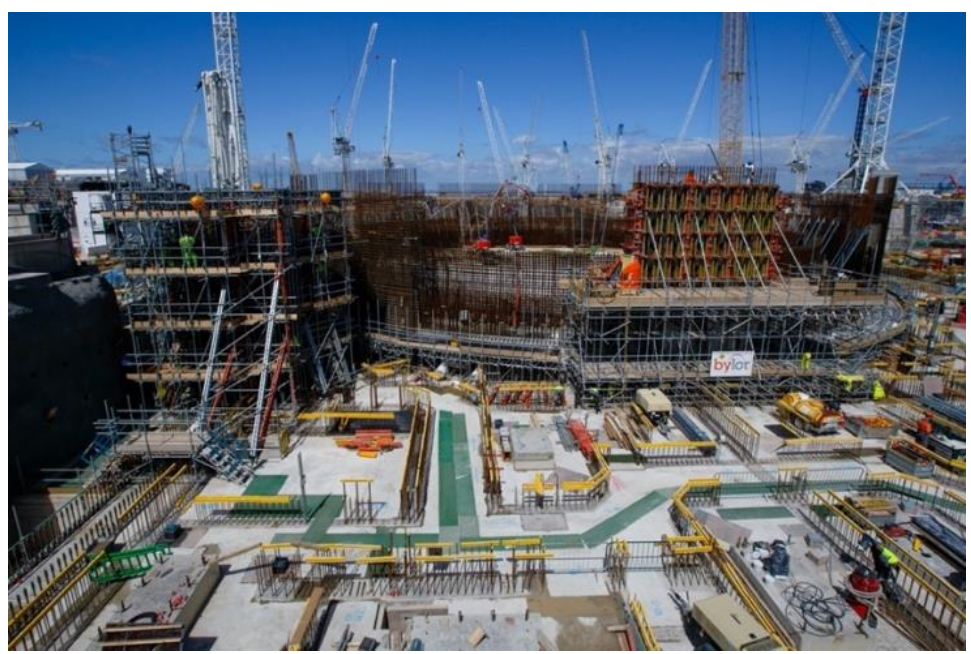

Figure 14: A construction site

Figure 14. Morison, Rachel, and Rob Dawson. "Cranes surround Reactor Unit Two on the construction project for Hinkley Point C near Bridgwater, U.K, on July 28.

Photographer: Luke MacGregor/Bloomberg." Bloomberg, Bloomberg, 1 Aug. 2020, www.bloomberg.com/news/articles/2020-08-01/a-look-inside-britain-sbiggest-construction-site.

\section{General recycling procedures in construction sites:}

Recycling and separating recoverable waste materials created during development and rebuilding help improve the safety and cost-effectiveness of construction projects. New material pieces, packaging, old materials, and debris constitute recoverable materials. Recyclable or reusable waste is frequently leftover in a wide scope of sizes from new developments. Other construction projects might use large pieces of scrap material in their developmental activities. The packaging is of importance as well. The packaging may be sent back to the supplier to reuse. It may also be recycled with smaller pieces of scrap. This will decrease the large number of natural resources being consumed for making new raw materials. It will also save a large amount of energy as well as the money that is spent on making new materials. The construction using onsite recycling methods will have a competitive edge due to the current wave of environment conservation and green building importance ("Recycle 
Construction Waste to Save Money and the Environment."). Cost savings will also be major advantage as this will cut down the taxes at landfills. It will also cut down the cost of transportation and disposal that is usually required.

\section{C\&D statistics comparison}

The figures and tables present the classification of the production of $C \& D$ debris with respect to the activities and individual contribution of different materials in the total $C \& D$ debris. Table 6 shows that in 2012, the total generation of C\&D debris was 521 million tons, while the generation was 530 million tons, 534 million tons, 548 million tons, and 569 million tons in 2013, 2014, 2015, and 2017, respectively(see Figures 16, 17, 18, and 19) (see Tables 7 , $8,9$, and 10$)$. The $C \& D$ generation by activity was reported similarly in each year. The results indicate that concrete consumption contributes to the highest amount of waste among all materials during construction works. However, according to Figure 15, the contribution of drywall and plasters in the total $C \& D$ debris was more than that of concrete in the construction activities of drywall and plasters. The results show that in 2015, a significant amount of gypsum was present in the plaster and drywall products obtained during construction activities. The gypsum contributed $8 \%$ of 13,042 thousand tons of $C \& D$ debris related to drywall and plaster. Furthermore, approximately $90 \%$ of the total C\&D debris production from all materials, except drywall and plaster, comes from the demolition, making it the most significant factor behind C\&D debris generation (“Advancing Sustainable Materials Management: Facts and Figures Report.”). All statistics are shown below (see Figures and Tables below). 


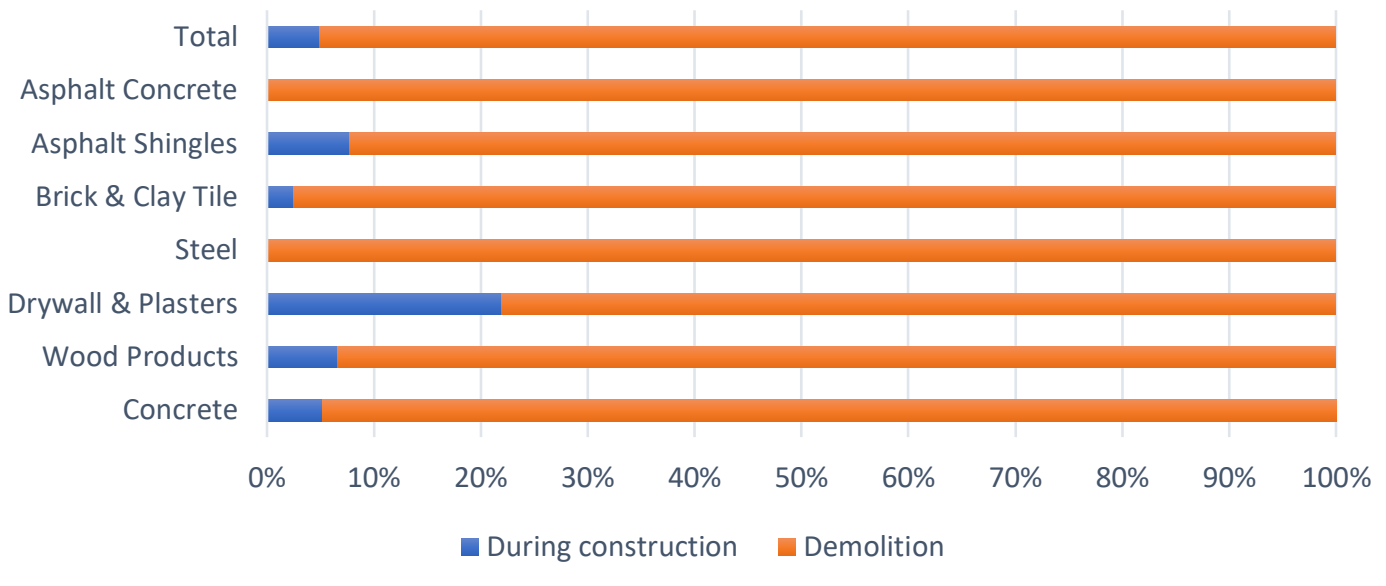

Figure 15: Contribution of construction and demolition phases to total $2012 C \& D$ debris generation

Figure 15. "C\&D Debris Generation by Material and Activity (thousand tons)." EPA, Environmental Protection Agency, Sept. 2018, www.epa.gov/sites/production/files/2018-09/documents/construction and_demolition_debris_generation_in_the united_states_2015_final.pdf.

\begin{tabular}{cccc}
\hline & $\begin{array}{c}\text { Waste during } \\
\text { Construction } \\
\text { (million tons) }\end{array}$ & $\begin{array}{c}\text { Waste during } \\
\text { Demolition } \\
\text { (million tons) }\end{array}$ & Total C\&D \\
\hline Concrete & 19.0 & 345.4 & 364.4 \\
\hline Wood Products & 2.5 & 35.2 & 37.7 \\
\hline Drywall \& Plasters & 2.7 & 9.6 & 12.3 \\
\hline Steel & 0 & 4.2 & 4.2 \\
\hline Brick \& Clay Tile & 0.3 & 11.9 & 12.17 \\
\hline Asphalt Shingles & 0.97 & 11.6 & 12.574 \\
\hline Asphalt Concrete & 0 & 77.8 & 77.8 \\
\hline Total & 25.44 & 495.70 & 521.144 \\
\hline Percentage out of total & $4.9 \%$ & $95.1 \%$ & $100 \%$ \\
\hline
\end{tabular}

Table 6: C\&D debris generation by source (million tons) Year of 2012

Source: "C\&D Debris Generation by Material and Activity (thousand tons)." EPA, Environmental Protection Agency, Sept. 2018, www.epa.gov/sites/production/files/2018-09/documents/construction_and_ demolition debris generation in the united states 2015 final.pdf. 


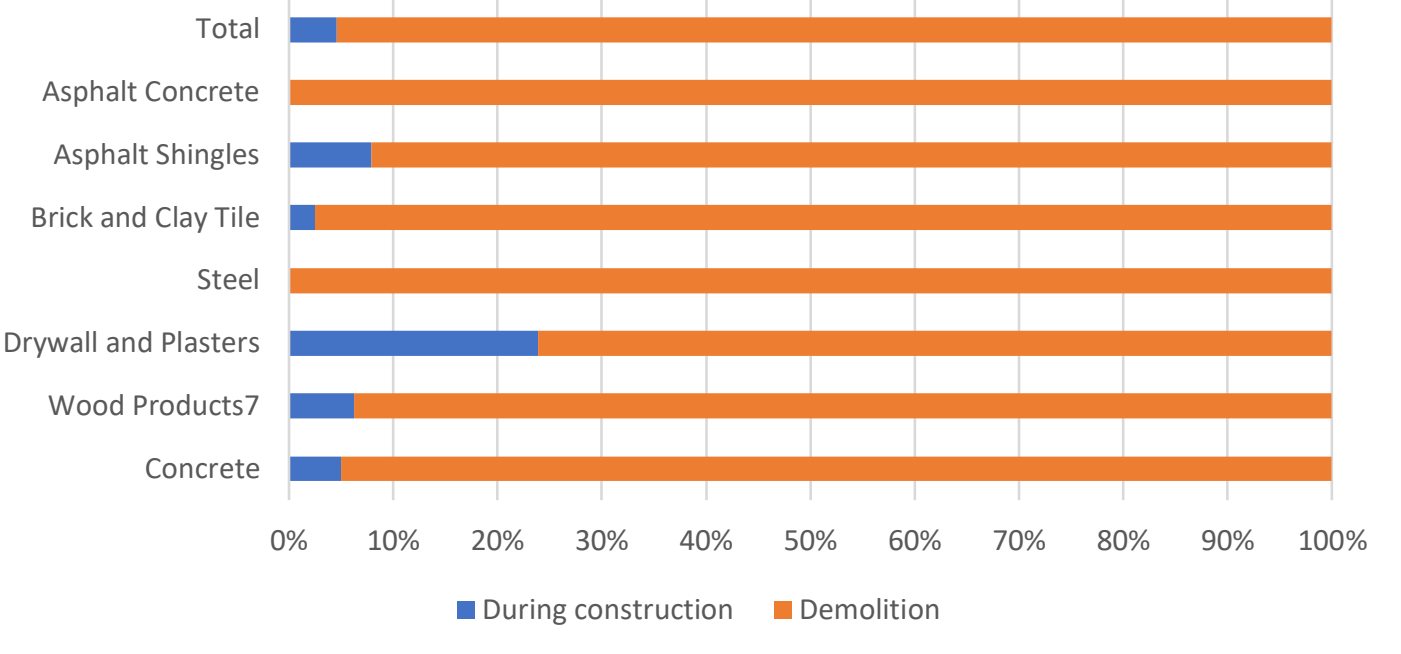

Figure 16: Contribution of construction and demolition phases to total 2013 C\&D debris generation

Figure 16. "Contribution of Construction and Demolition Phases to Total 2013 C\&D Debris Generation.” EPA, Environmental Protection Agency, Nov. 2019, www.epa.gov/sites/production/files/2019-11/documents/2017 facts and_figures_fact_sheet_final.pdf .

\begin{tabular}{cccc}
\hline C\&D Waste & $\begin{array}{c}\text { Waste during } \\
\text { Construction } \\
\text { (million tons) }\end{array}$ & $\begin{array}{c}\text { Waste during } \\
\text { Demolition } \\
\text { (million tons) }\end{array}$ & Total C\&D \\
\hline Concrete & 17.5 & 335.4 & 352.9 \\
\hline Wood Products & 2.5 & 37.7 & 40.2 \\
\hline Drywall \& Plasters & 3.1 & 9.9 & 13 \\
\hline Steel & 0 & 4.3 & 4.3 \\
\hline Brick \& Clay Tile & 0.3 & 11.8 & 12.1 \\
\hline Asphalt Shingles & 1 & 11.6 & 12.6 \\
\hline Asphalt Concrete & 0 & 95.1 & 95.1 \\
\hline Total & 24.4 & 505.8 & 530.2 \\
\hline Percentage out of total & $4.6 \%$ & $95.4 \%$ & $100 \%$ \\
\hline
\end{tabular}

Table 7: C\&D debris generation by source (million tons) Year of 2013

Source: "C\&D Debris Generation by Material and Activity (million tons)."EPA, Environmental Protection Agency, Nov. 2019, www.epa.gov/sites/production/files/2019-

11/documents/2017 facts and figures fact sheet final.pdf 


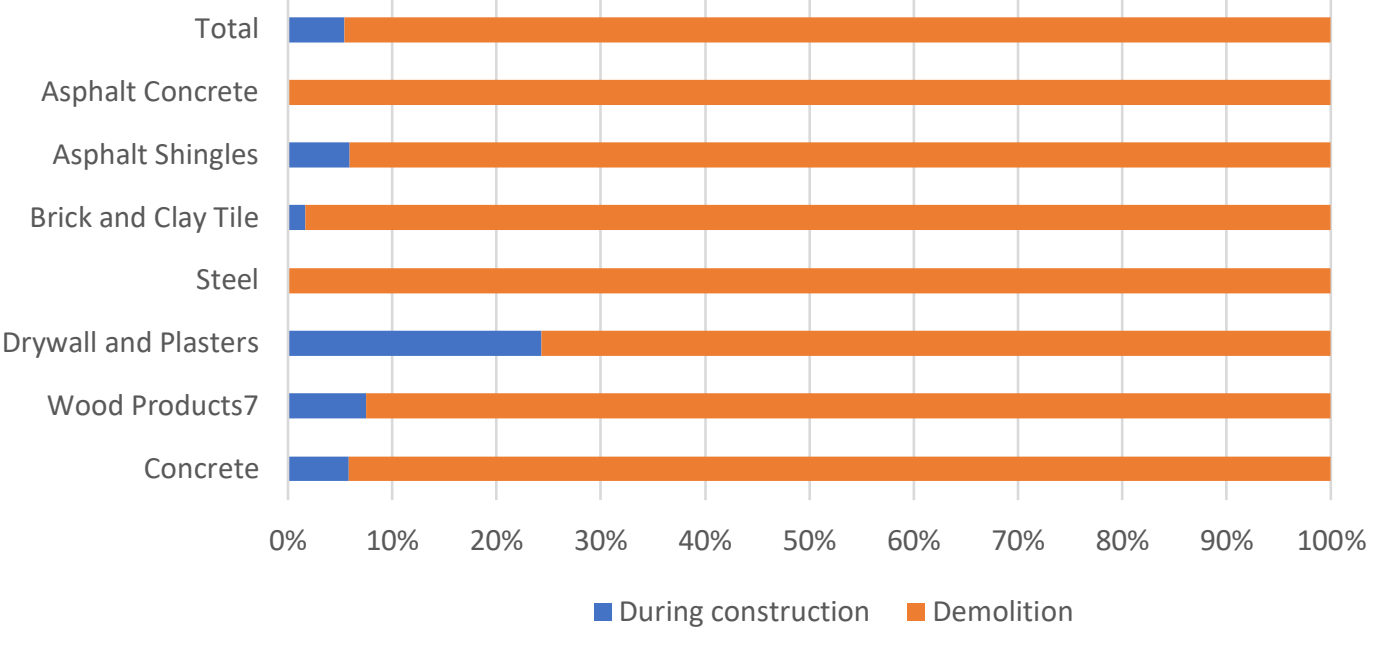

Figure 17: Contribution of construction and demolition phases to total $2014 C \& D$ debris generation

Figure 17. "Contribution of Construction and Demolition Phases to Total 2014 C\&D Debris Generation." EPA, Environmental Protection Agency, Nov.

2019, www.epa.gov/sites/production/files/2016-

11/documents/2014_smmfactsheet_508.pdf

\begin{tabular}{cccc}
\hline C\&D Waste & $\begin{array}{c}\text { Waste during } \\
\text { Construction } \\
\text { (million tons) }\end{array}$ & $\begin{array}{c}\text { Waste during } \\
\text { Demolition } \\
\text { (million tons) }\end{array}$ & Total C\&D \\
\hline Concrete & 21.7 & 353.6 & 375.3 \\
\hline Wood Products & 2.9 & 35.8 & 38.7 \\
\hline Drywall \& Plasters & 3.3 & 10.3 & 13.6 \\
\hline Steel & 0 & 4.3 & 4.3 \\
\hline Brick \& Clay Tile & 0.2 & 11.8 & 12 \\
\hline Asphalt Shingles & 0.8 & 12.7 & 13.5 \\
\hline Asphalt Concrete & 0 & 76.6 & 76.6 \\
\hline Total & 28.9 & 505.1 & 534 \\
\hline Percentage out of total & $5.4 \%$ & $94.6 \%$ & $100 \%$ \\
\hline
\end{tabular}

Table 8:C\&D debris generation by source (million tons) Year of 2014

Source: "C\&D Debris Generation by Material and Activity (million tons)." EPA, Environmental Protection Agency, Nov. 2019, www.epa.gov/sites/production/files/2016-

11/documents/2014_smmfactsheet_508.pdf 


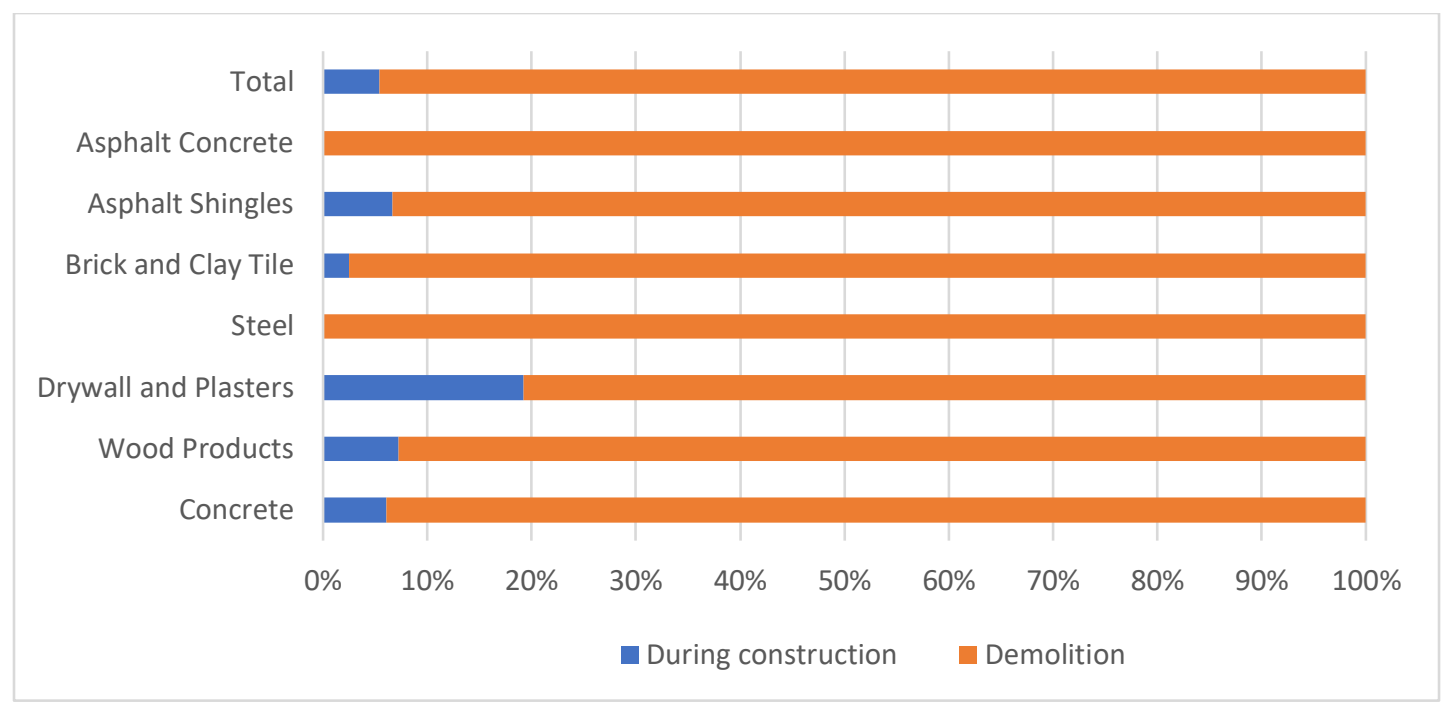

Figure 18: Contribution of construction and demolition phases to total 2015 C\&D debris generation

Figure 18. "Contribution of Construction and Demolition Phases to Total 2015 C\&D Debris Generation." EPA, Environmental Protection Agency, Nov. 2019, www.epa.gov/sites/production/files/2018-

07/documents/2015_smm_msw_factsheet_07242018_fnl_508_002.pdf

\begin{tabular}{cccc}
\hline C\&D Waste & $\begin{array}{c}\text { Waste during } \\
\text { Construction } \\
\text { (million tons) }\end{array}$ & $\begin{array}{c}\text { Waste during } \\
\text { Demolition } \\
\text { (million tons) }\end{array}$ & Total C\&D \\
\hline Concrete & 23.1 & 358.7 & 381.8 \\
\hline Wood Products & 2.8 & 36.1 & 38.9 \\
\hline Drywall \& Plasters & 2.5 & 10.5 & 13 \\
\hline Steel & 0 & 4.5 & 4.5 \\
\hline Brick \& Clay Tile & 0.3 & 11.9 & 12.2 \\
\hline Asphalt Shingles & 0.9 & 12.6 & 13.5 \\
\hline Asphalt Concrete & 0 & 83.9 & 83.9 \\
\hline Total & 29.6 & 518.2 & 547.8 \\
\hline Percentage out of total & $5.4 \%$ & $94.6 \%$ & $100 \%$ \\
\hline
\end{tabular}

Table 9: C\&D Debris generation by source (million tons) Year of 2015

Source: "C\&D Debris Generation by Material and Activity (million tons)."EPA, Environmental Protection Agency, Nov. 2019, www.epa.gov/sites/production/files/2018-

07/documents/2015_smm_msw_factsheet_07242018_fnl_508_002.pdf 


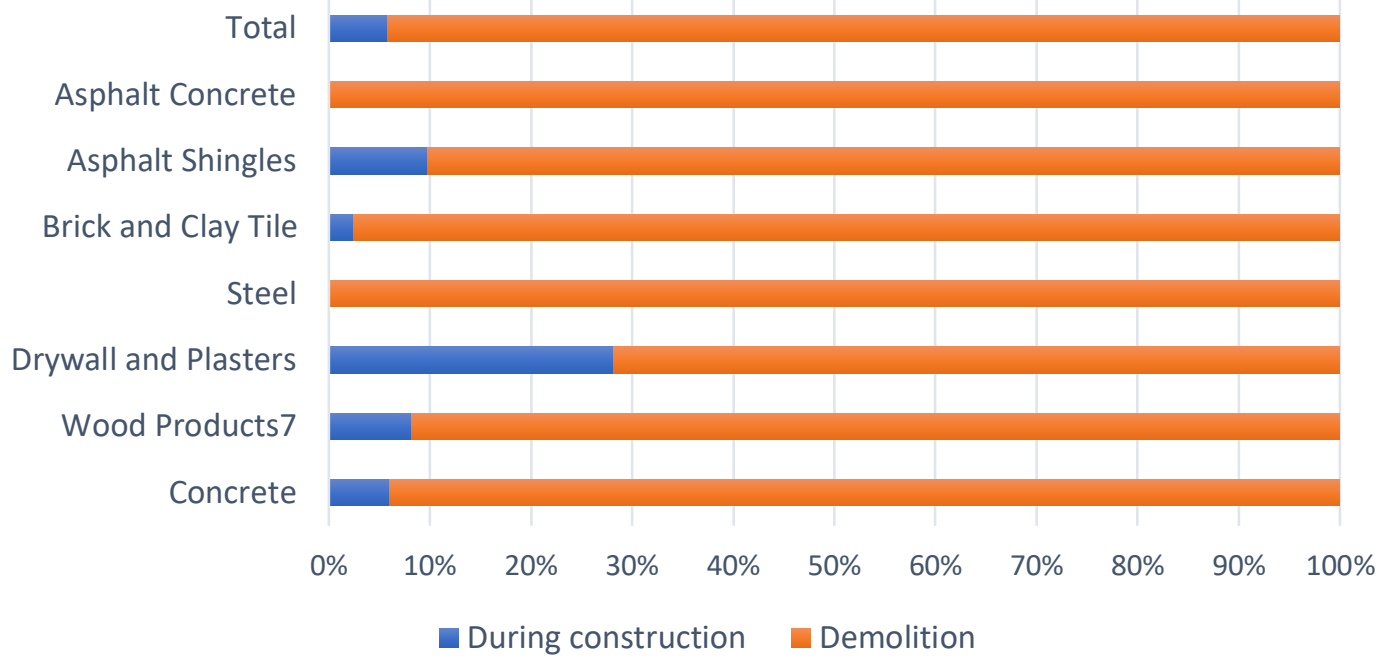

Figure 19: Contribution of construction and demolition phases to total 2017 C\&D debris generation

Figure 19. "Contribution of Construction and Demolition Phases to Total 2017 C\&D Debris Generation.” EPA, Environmental Protection Agency, Nov. 2019, www.epa.gov/sites/production/files/201911/documents/2017_facts_and_figures_fact_sheet_final.pdf

\begin{tabular}{cccc}
\hline C\&D Waste & $\begin{array}{c}\text { Waste during } \\
\text { Construction } \\
\text { (million tons) }\end{array}$ & $\begin{array}{c}\text { Demolition Debris } \\
\text { (million tons) }\end{array}$ & Total C\&D \\
\hline Concrete & 24 & 373 & 397 \\
\hline Wood Products & 3.3 & 36.9 & 40.2 \\
\hline Drywall \& Plasters & 4.3 & 11 & 15.3 \\
\hline Steel & 0 & 4.6 & 4.6 \\
\hline Brick \& Clay Tile & 0.3 & 11.9 & 12.2 \\
\hline Asphalt Shingles & 1.4 & 13 & 14.4 \\
\hline Asphalt Concrete & 0 & 85.7 & 85.7 \\
\hline Total & 33.3 & 536.1 & 569.4 \\
\hline Percentage out of total & $5.8 \%$ & $94.2 \%$ & $100 \%$ \\
\hline
\end{tabular}

Table 10: C\&D Debris generation by source (million tons) Year of 2017

Source: "C\&D Debris Generation by Material and Activity (million tons)." EPA, Environmental Protection Agency, Nov. 2019, www.epa.gov/sites/production/files/2019-11/documents/2017 facts and _figures_fact_sheet_final.pdf 


\section{Recover the cost of material from demolition construction projects}

The cost of recovery can be recovered from the handling of salvage materials. To avoid any damage during the salvage of the material, precise care should be taken, which comes at a price in addition to the standard cost. It is essential to eliminate components before a building demolition, which costs in the range of $\$ 2$ to $\$ 3$ per square foot of the building floor area. Table 11 shows the typical high recovery potential materials and/or components (Guyer, 2012).

\begin{tabular}{ccc}
\hline Appliances & Siding windows & Dimensional lumber \\
\hline Metal framing & wood beams & Cabinets \\
\hline soil & carpeting & insulation \\
\hline stairs & Bathroom fixtures & Doors \\
\hline Trim & Bricks & Ductwork \\
\hline Light fixtures & Marble & paneling \\
\hline Flooring & Shelving & Tile \\
\hline pipes & Plywood & \\
\hline
\end{tabular}

Table 11: Typical components/materials with a high recovery potential

Source: Guyer, J. Paul. "Typical Components/Materials with a High Recovery Potential." CEDengineering, CEDengineering, 2012, www.cedengineering.com/userfiles/Intro\%20to\%20Recycling\%20Constructio n\%20and\%20Demolition\%20Waste.pdf

The resale of the recovered materials offers significant returns. The cost of recovery can be balanced by profits obtained from the reuse or sale of salvaged material, which usually covers half the price of the new materials. Scrap dealers offer half or $25 \%$ of the original price of the construction material. Estimated salvage value for some generally recovered materials is listed in Table 12 based on the 1999 year values (Guyer, 2012). 


\begin{tabular}{|c|c|c|c|c|}
\hline Item & Description & Unit & $\begin{array}{c}\text { Retail Unit } \\
\text { Value }\end{array}$ & $\begin{array}{c}\text { Estimated } \\
\text { Salvage Value }\end{array}$ \\
\hline \multirow{5}{*}{ Metals } & Aluminum Scrap & Ton & & $\$ 480.00$ \\
\hline & Brass Scrap & Ton & & $\$ 560.00$ \\
\hline & Copper Scrap & Ton & & $\$ 980.00$ \\
\hline & Lead Scrap & Ton & & $\$ 380.00$ \\
\hline & Steel Scrap & Ton & & $\$ 35.00$ \\
\hline \multirow{2}{*}{ Oak Flooring } & 2-1/4" wide & $\mathrm{SF}$ & $\$ 2-\$ 2.50$ & $\$ 0.65-\$ 1.00$ \\
\hline & 3-1/4" wide & SF & $\$ 2-\$ 2.50$ & $\$ 0.65-\$ 1.00$ \\
\hline \multirow{4}{*}{$\begin{array}{l}\text { Framing Lumber } \\
\text { "higher" quality } \\
\text { (\#2) }\end{array}$} & 2 x $4\left(8^{\prime}-10^{\prime}\right)$ & EA & $\$=3.00$ & $\$ 0.90-\$ 1.10$ \\
\hline & $2 \times 4\left(12^{\prime}-14^{\prime}\right)$ & EA & $\$=4.50$ & $\$ 2.00-\$ 2.40$ \\
\hline & 2 x $8\left(12^{\prime}\right)$ & EA & $\$=8.75$ & $\$ 3.90-\$ 4.80$ \\
\hline & 2 x $8\left(14^{\prime}-15^{\prime}\right)$ & EA & $\$=10.00$ & $\$ 4.50-\$ 5.50$ \\
\hline \multirow{5}{*}{$\begin{array}{l}\text { Framing Lumber } \\
\text { "lower" quality } \\
\text { (construction } \\
\text { grade) }\end{array}$} & $2 \times 4\left(8^{\prime}-10^{\prime}\right)$ & EA & $\$=3.00$ & $\$ 0.30-\$ 0.75$ \\
\hline & $2 \times 4\left(8^{\prime}-10^{\prime}\right)$ & EA & $\$=4.50$ & $\$ 0.45-\$ 1.10$ \\
\hline & $2 \times 8\left(12^{\prime}\right)$ & EA & $\$=8.75$ & $\$ 0.90-\$ 2.20$ \\
\hline & 2 x $8\left(14^{\prime}-15^{\prime}\right)$ & EA & $\$=10.00$ & $\$ 1.00-\$ 2.50$ \\
\hline & $2 \times 12\left(10^{\prime}\right)$ & EA & $\$=10.00$ & $\$ 1.00-\$ 2.50$ \\
\hline Brick & Flush & EA & $\$ 0.30-\$ 0.35$ & $\$ 0.10-\$ 0.20$ \\
\hline \multirow{3}{*}{$\begin{array}{l}\text { Windows (double- } \\
\text { glased, aluminum } \\
\text { replacements) }\end{array}$} & $31 "$ x 54" & EA & $\$ 90-150$ & $\$ 15-\$ 30$ \\
\hline & $34 "$ x 45" & EA & $\$ 90-150$ & $\$ 15-\$ 30$ \\
\hline & $20 "$ x 36" & EA & $\$ 90-150$ & $\$ 10-\$ 15$ \\
\hline \multirow{4}{*}{ Doors } & 36" ext. panel & EA & & $\$ 0-\$ 15$ \\
\hline & 18" paneled & EA & & $\$ 5-\$ 10$ \\
\hline & 24"paneled & EA & & $\$ 5-\$ 10$ \\
\hline & 30" paneled & EA & & $\$ 5-\$ 10$ \\
\hline Tubs/toilets/sinks & $\begin{array}{l}\text { Cast iron tub/ } \\
\text { stainless steel }\end{array}$ & EA & & $\$ 5-\$ 10$ \\
\hline Stair Units, treads & $\begin{array}{l}\text { Oak treads/ units } \\
\text { include stringers }\end{array}$ & EA & & $\$ 25-\$ 50$ \\
\hline
\end{tabular}

Table 12: Salvage values for some recovered materials

Source: Guyer, J. Paul. "Estimated Salvage Values for Some Commonly Recovered Materials." CEDengineering, CEDengineering, 2012, www.cedengineering.com/userfiles/Intro\%20to\%20Recycling\%20Constructio n\%20and\%20Demolition\%20Waste.pdf

In order to handle and manage the resale operations, some additional resources are required. The storage is required for the recovered materials, which adds rent of storage space 
to the overall cost. If the recovered material can be reused for other works, it saves a considerable amount of money in many ways, such as hauling and dumping expenses are saved as well as the requirement of new material is also eliminated. For instance, the concrete, if recovered, can be crushed and used as fill material on construction sites. The availability of natural resources depends on the region, i.e., the material resale industry essentially exists in resource-deprived regions. The West Coast region (including California, Nevada, Oregon, Washington, and Idaho) and the southwest region (including Arizona, New Mexico, Texas, Oklahoma, Arkansas, and Louisiana) contain active markets for used materials. The usage of recovered materials significantly reduces the overall building cost, but, on the other hand, the potential of generating income through the reuse of materials is very low. Moreover, the bid price for the demolition of buildings is considerably reduced with the inclusion of recovered material. Several case studies prove that the process of recovery and recycling of components results in saving money in the range of a few cents to $\$ 4$ or $\$ 5$ per square foot of the building (Guyer, 2012).

\section{The following are the steps in salvaging demolition waste:}

1. Clean salvaged items.

2. Pack or crate items after cleaning. Identify contents of containers.

3. Store items in a secure area until installation.

4. Protect items from damage during transport and storage.

5. Install salvaged items to comply with installation requirements for new materials and equipment. Provide connections, supports, and miscellaneous materials necessary to make items functional for use indicated. ("Construction Waste Management, Section 0174 19.”) 


\subsection{On-site recycling process}

\section{Waste reduction work plan}

The following is an example of a waste reduction work plan from the EPA. The work plan needs to list each type of waste and whether it will be salvaged, reused, recycled, or disposed of in a landfill or incinerator.

1. Salvaged Materials for Reuse: For materials that will be salvaged and reused in this Project, describe methods for preparing salvaged materials before incorporation into the Work.

2. Salvaged Materials for Sale: For materials that will be sold to individuals and organizations, include a list of their names, addresses, and telephone numbers.

3. Salvaged Materials for Donation: For materials that will be donated to individuals and organizations, include a list of their names, addresses, and telephone numbers.

4. Recycled Materials: Include a list of local receivers and processors and the type of recycled materials each will accept. Include names, addresses, and telephone numbers.

5. Disposed Materials: Indicate how and where materials will be disposed of. Include the name, address, and telephone number of each landfill and incineration facility.

6. Handling and Transportation Procedures: Describe methods that will be used for separating recyclable waste, including sizes of containers, container labeling, and designated location on Project Site where materials separation will be located. (“Construction Waste Management, Section 0174 19.”)

\section{Jobsite sorting}

Jobsite sorting is what takes place at the very first place where the waste materials have been found. For instance, there are various places, such as construction companies and 
manufacturing companies, where waste materials are likely to be sorted before any other process occurs. Workers who are involved in the construction processes would be provided with certain guidelines and policies on how to sort out the materials at the place of work (Napier, 2016).

Wood is one of the dominant waste materials from North America at $30 \%$ of the total wastes (Napier, 2016 ). Again, the author notes that 25\% and 20\% are from industrial wastes and gravel, small stones, concrete chips, and similar materials, respectively. Disposal as refuse also accounts for about $5 \%$, while window glass is about $0.5 \%$ of the total waste materials in the country. The statistics provide some insight into the kind of wastes that the government should give attention to. At this stage, materials are also sorted in several containers that would ensure they are categorized based on the waste material.

\section{Start sorting as waste is produced}

It can really be a difficult and exhausting job to sift through the $C \& D$ waste material after the construction activities are completed. However, if the waste materials are segregated along with the construction activities, the waste can be sorted in an easy and organized manner. For instance, piling up the concrete waste separately on the day when concrete activities are carried out and sorting the metal pipes on the day when lines and piping work is done makes the process simpler and easier. It might take some extra time on that particular day but saves considerable time and energy from a larger perspective ("Tips for Sorting Construction Materials to Recycle."). 


\section{Avoid over sorting}

Sometimes over sorting can also be daunting. The materials that can be categorized under the same family can be sorted together rather than making extra piles for each material. As an example, one can put Asphalt, rubble, and concrete in one pile as they can be recycled together. However, all the materials cannot be recycled together. It's always a good choice to sort these types of material separately, such as Copper and Steel. Both of them are metals, but their recycling process or recycling facilities can differ in nature, so putting them both together can cause trouble later on (“Tips for Sorting Construction Materials to Recycle.”). In order to avoid extra work and expenditure at the end of the construction, a smart approach is to get familiar with the policies and practices of the recycling facilities to be used. The preemptive approach might take a little extra time beforehand, but it will save time and money to be spent later on (“Tips for Sorting Construction Materials to Recycle.”).

\section{Collection and hauling}

This is where the containers that are containing the waste materials are transported to the places where they would be recycled. At this stage, light trucks and even heavy ones are used to transport the materials. All this depends on the type of material being transported. Transportation has to take place given that there are only designated places where the recycling has to take place, and not any other place. Again, it should be noted that collection is key to make the manufacturing or production areas, as well as construction sites, safer for the people around.

\section{Site access}

The effect of site accessibility and conditions on the effectiveness of the recycling is significantly reduced if the debris from the material is removed off-site. If debris is to be 
removed on-site and pick-up is required, it necessitates the space to carry out the separation process and collection receptacles. Moreover, additional space for mobile crushers, screens, and sorted material is required if processing activities are done on-site. The availability of enough space for the abovementioned purpose is also a challenge (Guyer, 2012).

The activities of separation, processing, and removal of recovered materials require additional space per square $\mathrm{ft}$ at each building site. The usage of the recovered material on-site is the most economical and viable option, but if there is no on-site requirement, it is transported to local markets. For transportation activities, each building must have space for truck access. With no or insufficient space availability for trucks, the recovery and/or re-use plan is negatively affected (Guyer, 2012 ). Therefore, the waste management activities must be carried out while having as least as a possible intervention with roads, streets, walkways, and other engaged facilities.

- Conduct waste management operations to ensure minimum interference with roads, streets, walks, walkways and other adjacent occupied and used facilities.

- Designate and label specific areas on Project Site necessary for separating materials that are to be salvaged, recycled, reused, donated, and sold.

- Recycling and waste bin areas are to be kept neat, and clean, and clearly marked in order to avoid contamination of materials. ("Construction Waste Management, Section 0174 19.”)

\subsubsection{Recycling demolition waste processes}

Demolition waste is very valuable if treated well, therefore following the EPA processes help to get the most beneficial outcomes: 
A. Asphaltic Concrete Paving: Break up and transport paving to an asphalt recycling facility or recycle on-site into new paving.

B. Concrete: Remove reinforcement and other metals from concrete and sort with other metals.

1. Pulverize concrete to a maximum 4-inch (100-mm) size.

C. Masonry: Remove metal reinforcement, anchors, and ties from masonry and sort with other metals.

1. Pulverize masonry to maximum 1-1/2-inch (38-mm) size.

2. Clean and stack undamaged, whole masonry units on wood pallets.

D. Wood Materials: Sort and stack members according to size, type, and length. Separate lumber, engineered wood products, and panel products for reuse and/or recycling. Separate wood material treated with heavy metal preservatives for reuse or landfill disposal.

E. Metals: Separate metals by type.

1. Structural Steel: Stack members according to size, type of member, and length.

2. Remove and dispose of bolts, nuts, washers, and other rough hardware.

F. Asphalt Shingle Roofing: Separate organic and glass-fiber asphalt shingles and felts for recycling into asphalt paving or by other recycling entities.

G. Gypsum Board: Stack large, clean pieces on wood pallets and store in a dry location for recycling off-site. Remove edge trim and sort with other metals. Remove and dispose of fasteners.

1. Moisture-damaged gypsum board with evidence of significant mold growth shall be disposed of in accordance.

H. Acoustical Ceiling Panels and Tile: Stack large, clean pieces on wood pallets and store in a dry location. 
1. Separate suspension system, trim, and other metals from panels and tile and sort with other metals.

I. Carpet and Pad: Roll large pieces tightly after removing debris, trash, adhesive, and tack strips.

1. Store clean, dry carpet and pad in a closed container or trailer provided by a carpet recycler or manufacturer-related carpet reclamation agency.

J. Equipment: Drain tanks, piping, and fixtures. Seal openings with caps or plugs. Protect equipment from exposure to weather.

K. Plumbing Fixtures: Separate by type and size.

L. Piping: Reduce piping to straight lengths and store by type and size. Separate supports, hangers, valves, sprinklers, and other components by type and size.

M. Lighting Fixtures: Separate lamps by type and protect them from breakage.

N. Electrical Devices: Separate switches, receptacles, switchgear, transformers, meters, panelboards, circuit breakers, and other devices by type.

O. Conduit: Reduce conduit to straight lengths and store by type and size. (“Construction Waste Management, Section 0174 19.”)

\subsubsection{Recycling construction waste processes}

New construction waste can be reused and recycled on-site by following proper processes provided by EPA:

A. Packaging:

1. Cardboard and Boxes: Break down packaging into flat sheets. Bundle and store in a dry location.

2. Polystyrene Packaging: Separate and bag materials. 
3. Pallets: As much as possible, require deliveries using pallets to remove pallets from Project Site. For pallets that remain on-site, break down pallets into component wood pieces, and comply with requirements for recycling wood.

4. Crates: Break down crates into component wood pieces and comply with requirements for recycling wood.

B. Site-Clearing Wastes: Chip brush, branches, and trees on-site.

C. Wood Materials:

1. Clean Cut-Offs of Lumber: Grind or chip into material appropriate for mulch or erosion control.

2. Lumber Treated with Heavy-Metal Preservatives: Do not grind, chip, or incinerate; must be reused or landfilled.

D. Gypsum Board: Stack large, clean pieces on wood pallets and store in a dry location for recycling and/or reuse on-site or off-site.

1. Moisture-damaged gypsum board with evidence of significant mold growth shall be disposed of in accordance.

2. Clean Gypsum Board: Grind scraps of clean gypsum board using small mobile chipper or hammer mill. Screen out paper after grinding.

E. Miscellaneous: Anything called out to be ground and used on-site should utilize an on-site grinder.

1. The grinder should be able to accommodate a variety of materials, including masonry, asphalt shingles, wood, and drywall. ("Construction Waste Management, Section 0174 19.”) 


\section{Diversion or disposal}

At this stage, the materials are processed for reuse, and the ones that cannot be reused are also taken to landfills. Those materials that would be deposited in landfills are those that do not have the market and the ones that have been ruined. These materials also include refusing as well as contaminated materials that cannot be recycled. In every step, there needs to be careful when it comes to the materials that are contaminated. These materials could end up not being accepted in the market or not properly being recycled if not well sorted (“Construction Waste Management, Section 0174 19.”).

All the materials which are not subject to salvage, recycling, or reuse should be eliminated from the project site. They should be disposed of in a landfill or incinerated as per acceptable standards. The to-be-disposed waste material should not be accumulated on the site, except specified otherwise. The handling and transportation of the waste material should be carried out while avoiding spillage on the surfaces. The combustion of waste material is to be avoided. If the ground gypsum, wood, or other on-site material is used as granulated filler, it is not considered as waste material; instead, it's categorized under reuse ("Construction Waste Management, Section 0174 19.”).

\subsection{Construction materials on site}

Recycling all construction wastes is not always a good idea because some of the wastes might negatively affect the environment, safety, and economy. Construction debris consists of many materials, some of which are harmful when reusing or recycling, such as Polychlorinated Biphenyls PCB, mercury, lead, and asbestos. Also, most of the construction debris has positive impacts when reusing or recycling. Here is the common waste material: concrete, wood, 
gypsum drywall, and Asphalt. So, this chapter discusses the advantages of each material and how they can benefit the environment, safety, economy.

\subsubsection{Most useful materials in construction sites}

Here are the most useful materials in any construction site and their properties. The sites included are demolition, deconstruction, new construction, and renovation. Furthermore, all these types of materials are recyclable.

\section{Concrete}

The leftover debris after demolition of roadways and structures is reused and is called concrete recycling. As compared to in the past, the debris is recycled nowadays to reduce the construction cost as well as to cope with environmental issues. Advantages of recycled concrete on site:

- Recycled concrete is a high-quality concrete

- Recycled concrete is an accepted source of aggregate for new concrete

- Recycled concrete is better performance than virgin aggregates

- Recycled concrete provides for superior compaction and constructability.

- Recycled concrete is a higher yield, and that improves the overall project expenses because recycled aggregates are less weight per cubic yard.

- Recycled concrete weighs (10\%-15\%), which is lighter than virgin concrete.

- Recycling concrete helps to reduce landfill waste streams. (“Concrete.”)

It is important to realize how much benefits could be obtained from properly dealing with debris generation. It has been shown that concrete is the most material found in debris from the C\&D sites. Therefore, it increased the debris generation drastically throughout the years. An example of this is explained below. 
Millions of dollars were saved by reusing almost 700,000 tons of aggregate concrete in the Interstate 5 Improvement Route 22 Freeway to Route 9 Freeway project in Anaheim, California. Dan Cop Crushing Corp. of Anaheim, California, used portable crushers to recycle concrete and asphalt stockpiles to CL II aggregate-based materials as per requirements of California Department of Transportation's (Caltrans). Caltrans allows the use of recycled aggregate for road base material (“Case Histories.").

Due to Angel Stadium, Arrowhead Pond, and Disneyland, the development of this section of Interstate 5 was the highest-profile. Furthermore, the challenges like narrowed working area, heavy metal from bridge demolition, diversions, and frequency of crushes to move in and out along with freeway medians were the challenges from a portable recycling point of view. Weather played a part during the El Niño year bringing heavy rain to Southern California ("Case Histories.").

A total of 800,000 tons of recycled aggregate was used for the completion of the project. Saving around $\$ 5$ millions of Caltrans over purchasing and hauling virgin aggregate as well as hauling and disposing of the existing material. Recycling was found not only found economically but also environmentally beneficial in this project (“Case Histories.”).

\section{Wood}

C\&D debris contains up to $40 \%$ wood ("Wood."). So, it is important to know the advantages and characteristics of wood in C\&D debris: 
- Typically dimensional lumber is most commonly seen as a wood aggregate generated during C\&D activities. However, composite panels, treated wood and plywood are also $C \& D$ materials that are commonly recycled.

- Compost and mulch are the two main products made from C\&D recycled wood. However, temporary roads, wood pellets, indeed, animal bedding or other new wood products can also be made.

- For compost and mulch, only natural, unpainted and non-treated wood is used. C\&D mulch lasts longer due to its dried nature as compared to virgin wood.

- The U.S Environmental Protection Agency has acknowledged the C\&D biomass as a valid fuel. C\&D biomass has been exempted from Non-Hazardous Secondary Materials Rule due to its clean nature and is being used in paper manufacturing plants, cement kilns and waste to energy facilities.

- C\&D wood is an excellent material for wood pellets, fuel as well as energy recovery because of its extra dry nature.

- Preservatives such as creosote, chlorophenol and copper chromatedaresenate (CAA) must be removed properly from treated wood before it is prepared for an end product. ("Wood.”) (see Figure 20)

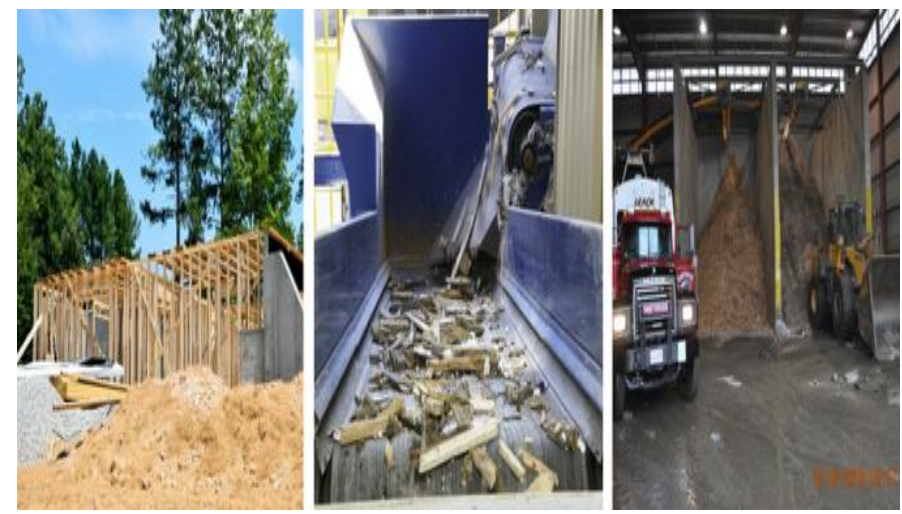

Figure 20:Wood recycling

Figure 20. "Wood recycling." Construction \& Demolition Recycling Association, CDRA, 2020, www.cdrecycling.org/materials/wood/ 


\section{Gypsum drywall}

Recycling gypsum drywall has been recently proposed for C\&D material management. This idea involves grinding of scrap drywall from construction sites, followed by applying reduced material as a plant nutrient or soil improver. This procedure offers potential economic benefits from costing less than traditional removal of drywall ("Gypsum Drywall."). Scrap gypsum drywall is currently being recycled in several locations in North America. Examples include:

- The manufacture of new drywall

- Use as an ingredient in the production of cement

- Application to soils and crops to improve soil drainage and plant growth

- A major ingredient in the production of fertilizer products

- An additive to composting operations. (“Gypsum Drywall.”) (see Figures 21 and 22)

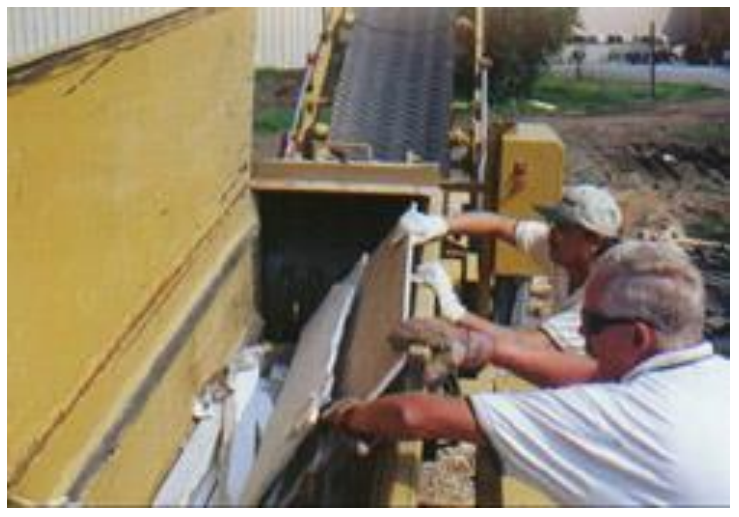

Figure 21: Scrap drywall being loaded into a mobile grind

Figure 21. "Scrap drywall being loaded into a mobile grinder." Construction \& Demolition Recycling Association, CDRA, 2020, www.cdrecycling.org/materials/gypsum-drywall/ 


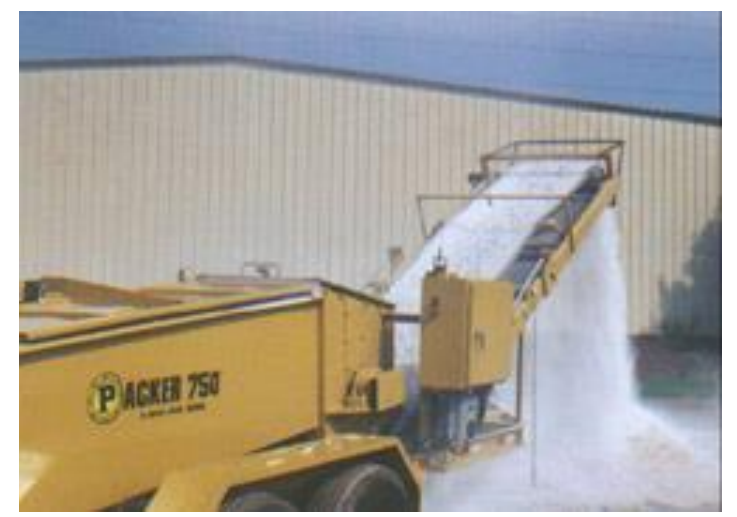

Figure 22:Drywall being ground using a mobile grinder

Figure 22. "Drywall being ground using a mobile grinder." Construction \& Demolition Recycling Association, CDRA, 2020, www.cdrecycling.org/materials/gypsum-drywall

\section{Asphalt}

Recycling of asphalt pavement advantages and characteristics:

- Reclaimed Asphalt Pavement (RAP) can be recycled multiple times into higher quality pavements than all virgin materials. The asphalt cement holds its capability and can be reused to hold the pavement together.

- Recycling of different materials from other industries like blast and steel furnace slags, tires, and asphalt roofing shingles into asphalt pavements is very common. RAP is often mixed with concrete and is being used as road base products. (“Asphalt Pavement”) (see Figure 23)

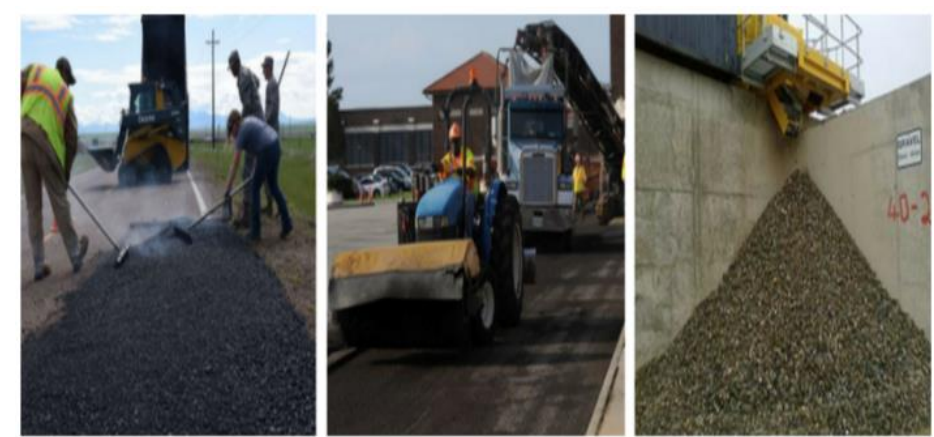

Figure 23: Asphalt pavement

Figure 23. "Asphalt Pavement." Construction \& Demolition Recycling Association, CDRA, 2020, www.cdrecycling.org/materials/asphalt-pavement/ 


\subsubsection{Possible harmful materials or waste on construction sites}

During the project planning phase, specific environmental requirements need to be checked. Code of federal regulations (29 CFR for OSHA, 49 CFR for transportation, and 40 CFR for environmental) pertain to federal requirements and are applicable in all states. In case of more strict state environmental requirements, they will be fulfilled to avoid any legal fines and obligations. Every state may have varying notification and disposal requirements for hazardous substances like Asbestos-containing materials (ACM), polychlorinated biphenyls (PCB), mercury, and lead-based paints (LBP). Many structures may contain PCB, LBP, ACM, and mercury; therefore, necessary precautionary measures must be taken to demolish and recycle these structures (Guyer, 2012).

\section{Polychlorinated biphenyls benzine (PCB)}

In the past, PCBs have been common components of heat transfer fluids, hydraulic fluids, insecticides, lubricants, rubber products, plastics, and plasticizers in paints. Certain paints and ceiling tile coatings also contain Non-liquid PCBs (NLPCBs). Depending upon the concentration and type of material (e.g., carbon paper, transformer, capacitor, etc.) containing PCBs, the disposal requirements and regulations may vary. C\&D debris is usually regulated as "PCB bulk product waste." Debris from the demolition of buildings or man-made PCBs contaminated structures that have not been decontaminated or cleaned up as per U.S.EPA requirements are not included in PCB Bulk product waste. However, PCB containing wastes from the household, shredding of automobiles, industrial appliances, white goods, insulations, fluorescent light ballasts, PCB impregnated electrical components, gaskets, and potting materials are other types of PB bulk product wastes (Guyer, 2012).

- Note: if there is no label showing "No PCBs," then it is assumed to contain PCBs. As shown (see Figure 24): 


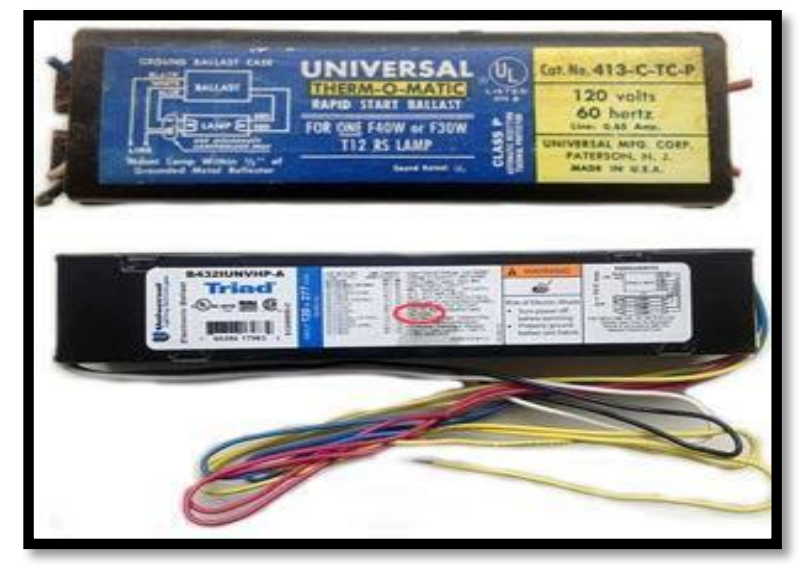

Figure 24: PCBs labels

Figure 24. "Comparison of pre-1979 ballast and new ballast." EPA, U.S. Environmental Protection Agency, 19 Jan. 2017, www.epa.gov/large-scaleresidential-demolition/light-systems-and-demolition\#pcbs

To prevent the release of PCBs:

- avoid breaking these items

- handle them separately from other demolition waste

- $\quad$ take them to an appropriate facility. (“Polychlorinated Biphenyls (PCBs).”)

\section{Mercury}

C\&D debris and construction sites may contain mercury. It can also be found in highintensity discharge lamps, fluorescent light bulbs, thermostats, relays, old mercury bearing wall switches, and gauges in pure elemental form or in the form of vapors. Wastes having these components and items must be labeled and characterized as hazardous ("Light Systems and Demolition Mercury.”). Note: According to EPA, mercury can be found in these bulbs and lamps types, as also shown (see Figure 25):

- Fluorescent bulbs

- Compact fluorescent light bulbs (CFLs)

- High-intensity discharge (HID) lamps 
- ultraviolet lamps

- neon lights. (“Light Systems and Demolition Mercury.”)

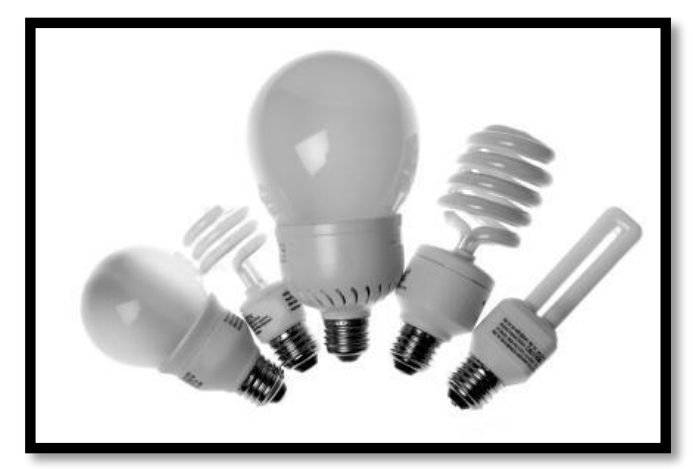

Figure 25: Bulbs \& lamps contain mercury

Figure 25. "Bulbs \& lamps contain mercury." EPA, U.S. Environmental Protection Agency, 19 Jan. 2017, www.epa.gov/large-scale-residentialdemolition/light-systems-and-demolition\#pcbs

"Silent" light switches, which were manufactured prior to 1991 and maybe present in older buildings, may also contain mercury.

- To prevent mercury contamination, these items should be isolated, labeled, and taken to a mercury recycler or consolidation site.

- To prevent the release of mercury, the mercury should not be removed from items, and fluorescent lamps should not be crushed. ("Light Systems and Demolition Mercury.")

\section{Lead}

Buildings before 1978 are coated with LBP, and these are primarily applied in baths, kitchens, and on wood trim and sidings. Lead contaminated debris is generated while performing demolition or abatement activities from an LBP-containing building. The U.S.EPA is proposing a new regulation for handling, storing, record keeping, and disposal of LBP to reduce the cost and difficulties with the disposal. Currently, as per the Resource Conservation 
and Reservation Act (RCRA), installations and facilities that have LPD debris equal to or exceeding 5mg/liter lead, as per EPA Toxicity Characteristic Leaching Procedure, are required to characterize their LBP waste and dispose of it by an approved method. This rule does not apply to LBP debris from residential buildings, as it is considered as non-hazardous per a policy clarification issued by the EPA in Aug 2000 on the disposal of LBP debris. Furthermore, OSHA based standards are in line for the workers exposed to Lead (Guyer, 2012).

Lead can be found in paint, specifically lead-based paint, which is commonly found in old buildings. During demolition processes, especially old buildings demolition, a lot of dust is generated that contains lead-based paint. One of the most common ways to lead to get into bodies is through the dust. Workers and the public will inhale this dust, or it could be easily transferred through air or sticking onto objects such as clothing. Not to mention that families could be exposed to lead from relatives that were exposed to lead dust. Hence, people could be exposed to lead to hazardous effects. Therefore, it is critical to follow the Lead-safe work practices in order to minimize lead-based paint dust and debris generated during demolition activities so that the workers would minimize their exposure to lead dust for themselves, their families, and their community.

\section{The best practices of minimizing dust contain lead:}

- Containing dust inside the work area

- Using dust-minimizing work methods

- Conducting a careful cleanup during the demolition. ("Lead-Based Paint and Demolition.") 


\section{Asbestos}

Due to its non-flammable nature, resistivity to chemicals corrosion, inexpensive and strong yet flexible nature, many different types of building materials contained asbestos at one time. (Guyer, 2012). Also, asbestos gets into the human body by inhaling it through the air, which impacts the respiratory system's tissues. Asbestos causes many fatal diseases, such as lung cancer. It could also take more than 20 years until symptoms appear in workers exposed to asbestos. ("Asbestos Standard for the Construction Industry.").

Most common sources of asbestos in the construction industry found in products such as:

- Sprayed-on fireproofing,

- Pipe insulation

- Floor tiles

- Cement pipe and sheet

- Roofing felts and Shingles

- Ceiling tiles

- Fire-resistant drywall

- Drywall joint compounds

- Acoustical products. ("Asbestos Standard for the Construction Industry.")

\section{Common construction activities where asbestos exposure can occur:}

- Demolishing or salvaging structures where asbestos is present.

- Removing or encapsulating asbestos-containing material (ACM).

- Constructing, altering, repairing, maintaining, or renovating asbestos-containing structures or substrates.

- Installing asbestos-containing products. 
- Cleaning up asbestos spills/emergencies.

- Transporting, disposing, storing, containing, and housekeeping involving asbestos or asbestos-containing products on a construction site. ("Asbestos Standard for the Construction Industry.”)

\section{The following helps to control asbestos in construction activities:}

- High-speed abrasive disc saws not equipped with a point-of-cut ventilator or enclosure with filtered exhaust air (see Figure 26).

- Compressed air to remove asbestos or ACM unless the compressed air is used with an enclosed ventilation system (see Figure 27).

- Dry sweeping, shoveling, or other dry cleanup of dust and debris.

- Employee rotation to reduce exposure. (“Asbestos Standard for the Construction Industry.").

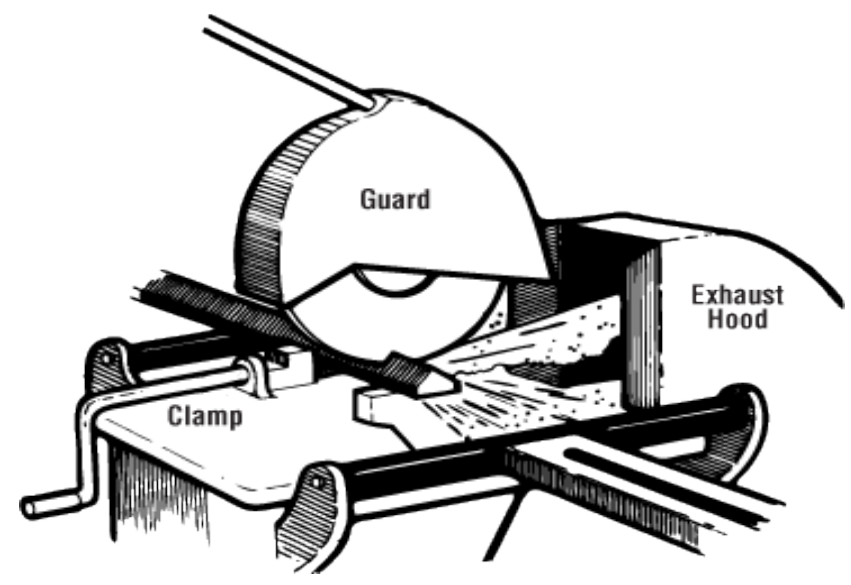

Figure 26:High-speed abrasive disc saws with filtered exhaust air

Figure 26."High-Speed Abrasive Disc Saws with Filtered Exhaust Air." CCOHS, Canadian Centre for Occupational Health \& Safety, 18 Dec. 2018, www.ccohs.ca/oshanswers/safety_haz/metalworking/metalsaws_hot.html 


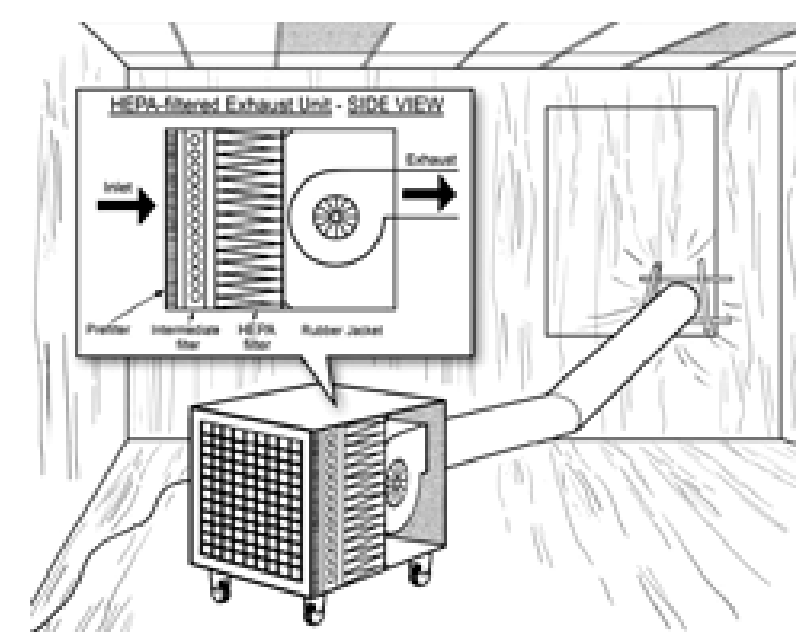

Figure 27: Enclosed ventilation system

Figure 27. "HEPA-Filtered Negative Air Unit." Labour, Ontario Ministry of Labour, Training and Skills Development, Nov. 2007, www.labour.gov.on.ca/english/hs/pubs/asbestos/asbst 11.php

\subsection{Best practices for reducing $C \& D$ waste}

As mentioned earlier, it is important to know the best practices in order to efficiently reduce waste from $C \& D$ sites. Through following the best practices, the Builders, construction teams, and design practitioners can avoid sending C\&D materials to landfills or basically avoid them being disposed of while they could still be used or sold or recycled. This process helps with recycling products, practicing source reduction, preserving existing structures, as well as salvaging and reusing existing materials.

\subsubsection{Designing for adaptability, disassembly, and reuse}

One of the best practices for reducing $C \& D$ waste and probably one of the smartest ones is to design the building or the project for adaptability. This also includes disassembly and reuse. Designing the building or the project this way helps in waste reduction while extending its useful life. This also provides economic and environmental benefits for builders, owners, and occupants, and the communities. With this practice, building removal will be avoided and will not be necessary anymore. Not to mention, it will be more cost-effective, and 
the building will be disassembled or taken apart much faster. Then all the materials recovered from that process could be recycled and reused in a different project or in a different way to benefit society. Not only design adaptability provides all the benefits mentioned earlier, but also it helps the design practitioners to find new ways while designing to reduce the negative environmental impacts, conserve resources, and reduce costs ("Best Practices for Reducing, Reusing, and Recycling Construction and Demolition Materials.”).

There are some strategies to follow while designing for adaptability, disassembly, and reuse. The EPA provided these to help attain the most beneficial outcome with the least mistakes while planning and designing. The strategies to follow are:

- Developing an adaptation or disassembly plan with key information (e.g., as built drawings, materials, key components, structural properties, and repair access and contact information).

- Using simple open-span structural systems and standard size, modular building components, and assemblies.

- Using durable materials that are worth recovering for reuse and/or recycling.

- Minimizing the use of different types of materials and making connections visible and accessible.

- Using mechanical fasteners such as bolts, screws, and nails instead of sealants and adhesives.

- Planning for the movement and safety of workers to allow for safe building adaptation, repair, and disassembly. ("Best Practices for Reducing, Reusing, and Recycling Construction and Demolition Materials.”) 


\subsubsection{Deconstructing buildings}

Disposal of C\&D materials is considered a waste of resources and landfill space, which results in pollution. This, unfortunately, happens when manufacturing new building materials. Therefore it makes more sense to follow deconstruction procedures. The deconstruction procedures can be applied on many levels to salvage the maximum number of usable materials and significantly reduce waste and disposal. These procedures range from reusing an entire structure or foundation to selecting assemblies and systems, to carefully removing specific materials or items for reuse ("Best Practices for Reducing, Reusing, and Recycling Construction and Demolition Materials.”).

It is always preferred to perform a complete deconstruction on a building/project since it is the most beneficial way to salvage the most amount of useful materials and the most sustainable method for removing or renovating a structure. However, it is not always possible to perform a complete deconstruction due to the type of project or building and its components being deconstructed. Therefore, the Department of Housing and Urban Development created a list of all the highly deconstructable buildings and their components. This list includes:

- Wood-framed buildings, especially those with heavy timbers and beams or with unique woods such as Douglas fir, American chestnut, and old-growth southern yellow pine, have "stick-by-stick" construction that lends easily to the deconstruction process. These kinds of lumber also have highly versatile reuses.

- Contain specialty materials with high resale value. These include items such as hardwood flooring, multi-paned windows, architectural moldings, and unique doors or plumbing/electrical material fixtures.

- Have high-quality brick-laid construction with low-quality mortar. This construction allows for the relatively easy break-up and cleaning. 
- Are structurally sound. Buildings with less rotted and decayed materials maximize the potential for deconstruction. ("Best Practices for Reducing, Reusing, and Recycling Construction and Demolition Materials.") 


\section{Chapter 4. Recommendations \& conclusion}

To conclude, this research conducted a literature review to understand better the status of $\mathrm{C} \& \mathrm{D}$ waste material generation and their impacts on, specifically, the environment, construction-related safety, and economy. Also, the practices in construction waste management were explored. This research presented recycling and reusing activities as the primary agents for managing the wastes resulted from $C \& D$ processes. Recycling $C \& D$ wastes play an important role in mitigating any adverse impacts on the environment, so make the C\&D activities eco-friendly.

The research shows that management of $C \& D$ waste is the best strategic measure to minimize harmful effects for the workers involved in the $C \& D$ related activities. The research confirmed that recycling $\mathrm{C} \& \mathrm{D}$ wastes are more cost-effective compared to conventional practice that transport the wastes to landfills, which brings economic benefits to nations. Also, activating the recycling industry is useful to provide more job opportunities for workers, increasing personal incomes, and tax revenues. The summary of findings from this research includes:

- Construction waste management is not taken seriously enough by most companies as seen through this research by highlighting the current practices that are used in C\&D waste materials.

- The best strategy to minimize harmful effects is by following the construction waste management hierarchy.

- Recycling C\&D waste is more cost-effective than sending construction waste to landfill. 
The following recommendations are made based on the findings in this research.

- Construction companies should develop and implement a plan consisting of waste identification, waste reduction process, and cost/revenue analysis before starting construction or demolition projects. It is important for companies to expect a lot of waste generated from their projects, therefore a proper plan needs to be implemented for the public's safety, the environmental safety, and to reduce the overall project cost:

- Having the waste identified would help save time in waste management since it helps the C\&D companies sort out the reusable and recyclable waste properly.

- Waste reduction planning also helps companies save time and money, hence the cost/revenue analysis is affected significantly by all the necessary planning mentioned.

- Cost and revenue analysis need to be made before $\mathrm{C} \& \mathrm{D}$ projects start. So, that will reduce the project expenses signficintaly. 


\section{Works cited}

“5 Best Recycling Practices." Compactor Management Company, Compactor Management Company, 29 July 2020, www.norcalcompactors.net/best-recycling-practices/

“50 Inspirational Home Remodel Before-And-Afters.” Choice Home Warranty, Choice Home Warranty, 2014, www.choicehomewarranty.com/50-inspirational-home$\underline{\text { remodel-before-after/ }}$

Abdel-Shafy, Hussein I. and Mona S. Mansour. "Solid Waste Issue: Sources, Composition, Disposal, Recycling, and Valorization." Egyptian Journal of Petroleum, Vol. 27, No. 4, 2018, pp. 1275-1290.

“About Green Building.” World Green Building Council, World Green Building Council, www.worldgbc.org/what-green-building

“Advancing Sustainable Materials Management: 2013 Fact Sheet.” EPA, EPA, June 2015, https://www.epa.gov/sites/production/files/2015-09/documents/2012_msw_fs.pdf

“Advancing Sustainable Materials Management: 2014 Fact Sheet.” EPA, Environmental Protection Agency, Nov. 2016, www.epa.gov/sites/production/files/2016$\underline{11 / \text { documents/2014_smmfactsheet_508.pdf }}$

“Advancing Sustainable Materials Management: 2015 Fact Sheet.” EPA, Environmental Protection Agency, July 2018, www.epa.gov/sites/production/files/201807/documents/2015_smm_msw_factsheet_07242018_fnl_508_002.pdf

“Advancing Sustainable Materials Management: 2016 Recycling Economic Information (REI) Report.” EPA, Environmental Protection Agency, Oct. 2016, www.epa.gov/sites/production/files/2017-05/documents/final_2016_rei_report.pdf 
“Advancing Sustainable Materials Management: 2017 Fact Sheet.” EPA, Environmental Protection Agency, Nov. 2019, www.epa.gov/sites/production/files/201911/documents/2017 facts and figures fact sheet final.pdf

“Advancing Sustainable Materials Management: Facts and Figures Report.” EPA, Environmental Protection Agency, 3 Apr. 2020, www.epa.gov/facts-and-figuresabout-materials-waste-and-recycling/advancing-sustainable-materials-management

"Asbestos Standard for the Construction Industry." OSHA, Occupational Safety and Health Administration, 2002, www.osha.gov/Publications/osha3096.pdf

“Asphalt Pavement Recycling." Construction \& Demolition Recycling Association, CDRA, 2020, www.cdrecycling.org/materials/asphalt-pavement/

“Asphalt Pavement." Construction \& Demolition Recycling Association, CDRA, 2020, www.cdrecycling.org/materials/asphalt-pavement/

Bailey, Kate. “Zero Waste Creates Jobs.” Ecocycle, Eco-Cycle, Inc, 2016, www.ecocycle.org/zerowaste/jobs

"Best Practices for Reducing, Reusing, and Recycling Construction and Demolition Materials.” EPA, Environmental Protection Agency, 28 Nov. 2018, www.epa.gov/smm/best-practices-reducing-reusing-and-recycling-construction-anddemolition-materials

Butcher, Mary Jo. “Overview: Renovation Projects.” PES Engineers -, 28 Feb. 2018, www.pesengineers.com/overview-renovation-projects/ 
"Bulbs \& Lambs Contain Mercury ." EPA, Environmental Protection Agency, 19 Jan. 2017, www.epa.gov/large-scale-residential-demolition/light-systems-anddemolition\#mercury

“Case Histories." Construction \& Demolition Recycling Association, CDRA, 2020, www.cdrecycling.org/materials/concrete/case-histories/

“Causes and Prevention.” Health and Safety Executive, HSE, 2020, www.hse.gov.uk/slips/preventing.htm

“Cleaning.” HSE, Health and Safety Executive, 2020, www.hse.gov.uk/slips/cleaning.htm

Cochran, Kimberly. "Recycling Construction Materials." Construction Business Owner, Cahaba Media Group, Inc, 2 June 2007, www.constructionbusinessowner.com/law/regulations/recycling-construction$\underline{\text { materials-important-part-construction-process }}$

“Comparison of Pre-1979 Ballast and New Ballast." EPA, Environmental Protection Agency, 19 Jan. 2017, www.epa.gov/large-scale-residential-demolition/light-systems-anddemolition\#mercury

“Concrete.” Construction \& Demolition Recycling Association, CDRA, 2020, www.cdrecycling.org/materials/concrete/

“Construction and Demolition Debris Generation in the United States, 2014." EPA, Office of Resource Conservation and Recovery, Dec. 2016, www.epa.gov/sites/production/files/201809/documents/construction_and_demolition_debris_generation_in_the_united_states_ 2015_final.pdf 
“Construction and Demolition Debris Management in the United States, 2015." EPA, Environmental Protection Agency, Mar. 2020, www.epa.gov/sites/production/files/2020-03/documents/final cd-eolmanagement_2015 508.pdf

“Construction Site.” Total Security Solution, Total Security Solution, 1 Aug. 2018, $\underline{\text { www.totalsecuritysolution.in/page/31/?s }}$

“Construction Waste Management, Section 0174 19.” EPA, Environmental Protection Agency. December 2007, https://www.epa.gov/sites/production/files/201403/documents/017419.pdf

"Demolition by Explosive ." The Constructor, The Constructor Civil Engineering Home , 2020, www.theconstructor.org/structures/demolition-methods-process-buildingsstructures/13941/

“Drywall Being Ground Using a Mobile Grinder.” Construction \& Demolition Recycling Association, CDRA, 2020, www.cdrecycling.org/materials/gypsum-drywall/on-siterecycling/

Grosse, François “Is Recycling Part of the Solution? The Role of Recycling in an Expanding Society and a World of Finite Resources," S.A.P.I.EN.S [Online], 3.1 |2010, online since 10 February 2010, connection on 06 November 2020. URL: http://journals.openedition.org/sapiens/906

"Four Demolition Projects Take Home Environmental Excellence Awards." For Construction Pros, For Construction Pros, 30 July 2012, 
Www.forconstructionpros.com/equipment/press-release/10735861/national$\underline{\text { demolition-association-four-demolition-projects-take-home-environmental- }}$ excellence-awards

Guyer, J. Paul. “An Introduction to Recycling Construction and Demolition Waste.” CEDengineering, CEDengineering, 2012, https://pdhonline.com/courses/c737/c737content.pdf

“Gypsum Drywall.” Construction \& Demolition Recycling Association, CDRA, 2020, www.cdrecycling.org/materials/gypsum-drywall/

"How Demolition Can Minimize Its Environmental Impact." DTSpecializedServices, DT Specialized Services, 1 Jan. 1970, www.dtspecializedservices.com/blog/posts/view/75/how-demolition-can-less-itsenvironmental-impact

"Industrial and Construction and Demolition (C\&D) Landfills." EPA, Environmental Protection Agency, 19 Jan. 2017, www.epa.gov/landfills/industrial-and-constructionand-demolition-cd-landfills

"Improvements Needed in EPA Efforts to Address Methane Emissions From Natural Gas Distribution Pipelines.” EPA, Environmental Protection Agency, 25 July 2014, www.epa.gov/sites/production/files/2015-09/documents/20140725-14-p-0324 0.pdf

Lamont, Hamish. "EnviroWaste - Separation at Source is Key to Construction Waste Minimisation." Homeco, Homeco, 21 May 2019, www.homeco.co.nz/blog/2019/5/20/envirowaste-separation-at-source-key-to$\underline{\text { construction-waste-minimisation }}$ 
“Lead-Based Paint and Demolition.” EPA, U.S. Environmental Protection Agency, 19 Jan. 2017, www.epa.gov/large-scale-residential-demolition/lead-based-paint-anddemolition

Lennon, Mark. "Recycling Construction and Demolition Wastes, A Guide for Architects and Contractors.” EPA, U.S. Environmental Protection Agency, Apr. 2005, www.archive.epa.gov/region1/healthcare/web/pdf/cdrecyclingguide.pdf

"Light Systems and Demolition Mercury." EPA, U.S. Environmental Protection Agency, 19 Jan. 2017, www.epa.gov/large-scale-residential-demolition/light-systems-anddemolition\#pcbs

Napier, Tom. “Construction Waste Management." WBDG, National Institute of Building Sciences, 17 Oct. 2016, www.wbdg.org/resources/construction-waste-management

"No Time to Waste; Waste Diversion in Construction." USGBC West Michigan, West Michigan Chapter, 12 Sept. 2017, www.usgbcwm.org/no-time-to-waste-wastediversion-in-construction/

“On-Site Recycling.” Construction \& Demolition Recycling Association, CDRA, 2020, www.cdrecycling.org/materials/gypsum-drywall/on-site-recycling

“OSWER Innovation Project Success Story: Deconstruction.” EPA, U.S. Environmental Protection Agency, Nov. 2009, www.epa.gov/sites/production/files/201603/documents/innovation_project_success_story_deconstruct.pdf

"Polychlorinated Biphenyls (PCBs)." EPA, U.S. Environmental Protection Agency, 19 Jan. 2017, www.epa.gov/large-scale-residential-demolition/light-systems-anddemolition\#pcbs 
"Preventing Slips and Trips at Work." HSE, Health and Safety Executive, Feb. 2014, www.hse.gov.uk/pubns/indg225.pdf

"Recycle Construction Waste to Save Money and the Environment." Compactor Management Company, Compactor Management Company, 11 June 2020, www.norcalcompactors.net/recycle-construction-waste/

“Recycling Basics.” EPA, U.S Environmental Protection Agency, 15 July 2020, www.epa.gov/recycle/recycling-basics

“Recycling Bins.” Homeco, Homeco, 20 May 2019, www.homeco.co.nz/blog/2019/5/20/envirowaste-separation-at-source-key-to$\underline{\text { construction-waste-minimisation }}$

“Recycling Concrete.” Construction \& Demolition Recycling Association, CDRA, 2020, www.cdrecycling.org/materials/concrete/

“Recycling: Collection.” OSHA, United States Department of Labor, 2008, www.osha.gov/SLTC/recycling/recycling_collection.html

"Recycling: Lifting Injuries." Occupational Safety and Health Administration, United States Department of Labor, 2020, www.osha.gov/SLTC/recycling/recycling_ergonomics.html

“Recycling: Traffic Safety, Loading and Unloading." Occupational Safety and Health Administration, United States Department of Labor, 2020, www.osha.gov/SLTC/recycling/recycling_traffic.html 
"Recycling." Occupational Safety and Health Administration, United States Department of Labor, 2020, www.osha.gov/SLTC/recycling/index.html

Rodriguez, Juan. "Demolition by Non-Explosive Method.” The Balance Small Business, The Balance Small Business, 14 June 2019, www.thebalancesmb.com/ways-to-demolishbuildings- 844420

“Scrap Drywall Being Loaded into a Mobile Grinder." Construction \& Demolition Recycling Association, CDRA, 2020, www.cdrecycling.org/materials/gypsum-drywall/on-siterecycling/.

"Slips and Trips: The Importance of Floor Cleaning." HSE, Health and Safety Executive, Sept. 2005, www.hse.gov.uk/pubns/web/slips02.pdf

“The Waste Management Hierarchy.” USGBC West Michigan, USGBC West Michigan Chapter, 12 Sept. 2017, www.usgbcwm.org/no-time-to-waste-waste-diversion-inconstruction/.

“Tips for Sorting Construction Materials to Recycle.” Zanker Recycling, Zanker Recycling, 5 Mar. 2020, www.zankerrecycling.com/tips-for-sorting-construction-materials-torecycle/.

Townsend, Timothy G., and Anshassi, Malak. "Benefits of Construction and Demolition Debris Recycling in the United States." CDRA, 1 Apr. 2017, www.nrcne.org/wpcontent/uploads/2019/12/cdra_benefits_of_cd_recycling_final_revised_2017.pdf

“Understanding Construction Projects.” Laws, Laws, 23 Dec. 2019, www.construction.laws.com/construction-projects. 
“Understanding the 4 Characteristics of Hazardous Waste." Hazardous Waste Experts, PEGEX, 24 Feb. 2014, www.hazardouswasteexperts.com/understanding-the-fourcharacteristics-of-hazardous-waste/

"Wood Recycling." Construction \& Demolition Recycling Association, CDRA, 2020, www.cdrecycling.org/materials/wood/

“Wood.” Construction \& Demolition Recycling Association, CDRA, 2020, www.cdrecycling.org/materials/wood/ 